\title{
Эндогенные процессы и связанный с ними рудогенез в фанерозое Воронежской антеклизы
}

\author{
(C2020 А. В. Черешинский ${ }^{凶}$, Л. Т. Шевырев, А. Д. Савко \\ Воронежский государственный университет, \\ Университетская пл., 1, 394018, Воронеж, Российская Федерация
}

\begin{abstract}
Аннотация
Введение: Образование и тектонические перестройки структуры Воронежской антеклизы сопровождались эндогенными процессами. Их влияние зафиксировано наличием в осадочном чехле вулканических пород и связанных с ними россыпей $\mathrm{Ti}$, сульфидов $\mathrm{Cu}, \mathrm{Pb}, \mathrm{Zn}$, интерметаллидов, алмазов и их минералов-спутников.

Методика: Составлены карты различного назначения, в т.ч. геологические, фациальные, минерагенические. Проводилось описание прозрачно-полированных шлифов и аншлифов. Препараты изучались под бинокуляром и с помощью электронно-микроскопического анализа (электронный микроскоп Jeol 6380LV). Для определения элементного состава использовался локальный рентгеноспектральный анализ (система OXFORD INS), полуколичественный спектральный анализ. Минеральный состав был исследован на порошковом рентгеновском дифрактометре ARL X'TRA,

Результаты и обсуждение: Эндогенное оруденение обычно развито в зонах фанерозойской активизации - линейных площадях, в которых проявлены тектонические процессы по глубинным разломам, по которым осуществлялась связь с коровыми и мантийными источниками. В этих зонах нарушена сплошность пород, и они становятся проницаемыми для магм, гидротерм и эксгаляций. Выделено шесть эпох проявления таких процессов: 1 - раннегерцинская $\left(\mathrm{D}_{2}-\mathrm{C}_{1}\right), 2-$ позднегерцинская $\left(\mathrm{C}_{2}-\mathrm{T}_{1}\right), 3$ - раннекиммерийская $\left(\mathrm{T}_{2}-\mathrm{J}_{1}\right), 4$ - позднекиммерийская $\left(\mathrm{J}_{2}-\mathrm{K}_{1}\right), 5-$ раннеальпийская $\left(\mathrm{K}_{2}-\mathrm{P}_{3}\right), 6$ - позднеальпийская $(\mathrm{N}-\mathrm{Q})$. B $\mathrm{D}_{2}-\mathrm{C}_{1}$ магматизм проявился в несколько этапов. Наиболее ранний из них щелочно-базальтовый в Калужско-Бельской структуре на севере антеклизы датирован эйфельским веком. Эксплозивный ястребовский на юго-востоке региона отвечает границе живета и франа. В начале позднефранского (петинского) времени, в меньшей степени в его конце (евлано-ливенского), были излияния толеитовых базальтов (потоковые и жерловые), образовавших несколько полей. Вулканизм связан с мантийными источниками, как и протерозойские гипербазиты с сульфидным медно-никелевым оруденением. Над ними отмечаются эксгаляционные позднегерцинские ореолы рассеяния $\mathrm{Ni}$, Co и $\mathrm{Cu}$ в осадочном чехле. В базальных горизонтах раннего карбона появляются минералы-спутники алмазов. В раннекиммерийскую эпоху образовались полиметаллы в терригенно-карбонатных образованиях каменноугольной системы в пограничных областях антеклизы и Днепровско-Донецкой впадины. Базальные горизонты $\mathrm{J}_{3}$ и $\mathrm{K}_{1}$ содержат мелкие алмазы и их минералы-спутники, свидетельствующие о кимберлитовом (лампроитовом) магматизме. Его новая вспышка была в раннеальпийскую эпоху, когда проявились гидротермальные процессы при формировании граносиенитовой протрузии Шкурлатского гранитного карьера. Флюиды, поступавшие при ее движении вверх, сформировали
\end{abstract}

\section{Контент доступен под лицензией Creative Commons Attribution 4.0 License.}

\footnotetext{
Черешинский Алексей Васильевич, E-mail: vsu31022@mail.ru
} 
по кораллиту анкеритовый метасоматит, обогащенный баритом, олигонитом, сфалеритом и другими минералами. Позднеальпийская эпоха отличается эксгаляционными процессами с образованием в осадочном чехле ультратонкого золота и интерметаллидов, обогащенных летучими металлами.

Заключение: Эндогенные процессы, наложенные на породы осадочного чехла, привели к формированию ряда полезных ископаемых, поиски и разведка которых могут привести к открытию новых для региона месторождений. С девонским магматизмом связаны вулканогенно-осадочные россыпи титана с содержанием ильменита до первых сотен кг $/ \mathrm{m}^{3}$, базальтов для производства балластного щебня и каменного литья. Базальты и россыпи ильменита на юго-востоке антеклизы имеются во вскрыше медно-никелевых, графитовых месторождений и над куполами гранитоидов, что открывает возможности для их комплексной отработки. Ценность месторождений увеличивают залегающие во вскрыше каолины, кварцевые пески, мела, кирпичные суглинки. Гидротермальные процессы привели к появлению руд полиметаллов на юго-западе антеклизы, где прослежена цепочка их проявлений в зонах развития глубинных разломов. В кайнозое с эскалациями в осадочный чехол связаны проявления ультратонкого золота, одно из которых Русская Журавка на юго-востоке выявлено в прошлом столетии. Но из-за трудностей извлечения металла (7-12\%) геологоразведочные работы не были продолжены. Проведенные исследования алмазоносности позволяют прогнозировать три эпохи кимберлитового магматизма - позднегерцинскую, позднекиммерийскую и раннеальпийскую. Наиболее достоверной из них является вторая. Поэтому кимберлиты в первую очередь следует искать под нижнемеловыми образованиями.

Ключевые слова: эндогенные процессы, вулканогенно-осадочные россыпи титана, базальты, ореолы рассеяния $\mathrm{Ni}$ и $\mathrm{Cu}$, полиметаллы, ультратонкое золото, алмазы, минералы-спутники алмазов.

Для циттирования: Черешинский А. В., Шевырев Л. Т., Савко А. Д. Эндогенные процессы и связанный с ними рудогенез в фанерозое Воронежской антеклизы // Вестник Воронежского государственного университета. Серия: Геология. 2020. №1. С. 6-29. DOI: https://doi.org/10.17308/geology.2020.1/2509

\section{Введение}

Образование и тектонические перестройки структуры Воронежской антеклизы (ВА) сопровождались эндогенными процессами. Их влияние зафиксировано наличием в осадочном чехле вулканических пород и связанных с ними россыпей $\mathrm{Ti}$, сульфидов $\mathrm{Cu}, \mathrm{Pb}, \mathrm{Zn}$, интерметаллидов, алмазов и их минералов-спутников.

Эндогенное оруденение обычно развито в зонах фанерозойской активизации - линейных площадях, где проявлены тектонические процессы по глубинным разломам и осуществлялась связь с коровыми и мантийными источниками. В этих зонах нарушена сплошность пород, и они становятся проницаемыми для магм, гидротерм и эксгаляций. Очень благоприятны для рудообразования зоны пересечения разломов, где максимальная трещиноватость и нередко образуются кольцевые структуры, связанные с просадкой или поднятием блоков кристаллического фундамента, внедрением протрузий гранитоидов и ультраосновных пород в осадочный чехол [1].

Воронежская антеклиза представляет собой выступ кристаллического фундамента Восточно-Европейской платформы размером 800х600 км (рис. 1), перекрытый осадочным чехлом мощностью от первых десятков метров на юге до 1.5 км в краевых частях рассматриваемой структуры. Осадочные образования представлены породами девонской, каменноугольной, юрской, меловой, палеогеновой, неогеновой и четвертичной систем (рис. 2).
Кристаллический фундамент разбит на блоки по тектоническим зонам, которые служили проводниками эндогенного вещества в осадочный чехол. Антеклиза как структура была образована по периферическим глубинным разломам в палеозое. В юрский период в ее центральной части сформировалось ДоноДонецкое поднятие. В мел-палеогеновое время она представляла северо-восточный борт Донецкой впадины, а в неоген-четвертичный этап в результате неотектонических положительных движений на рассматриваемой территории и южной части Московской синеклизы возникла Среднерусская антеклиза.

\section{Фактический материал и методы исследований}

В результате проведения геолого-съемочных (ГДП-200) и тематических работ за последнюю четверть века получен большой фактический материал по эндогенной минерализации пород осадочного чехла (рис. 3). Составлены карты различного назначения, в т.ч. геологические, фациальные, минерагенические. Установление эпох рудогенеза проводилось по появлению и исчезновению эндогенных ассоциаций в хорошо стратифицированных осадочных породах. Лабораторные анализы выполнены в Воронежском университете и других организациях. Проводились: а описание прозрачно-полированных шлифов и аншлифов; б - изучение препаратов под бинокуляром; в электронно-микроскопическое изучение (электронный микроскоп Jeol 6380LV); г - локальный рентгеноспектральный анализ элементного состава (система OXFORD INS); д - изучение минерального состава на порошковом рентгеновском дифрактометре ARL X'TRA, полуколичественный спектральный анализ.

При работе с частицами ультратонкого золота (УТЗ) и интерметаллидов размерностью в первые десятки мкм использовались лицензионные обогати- 


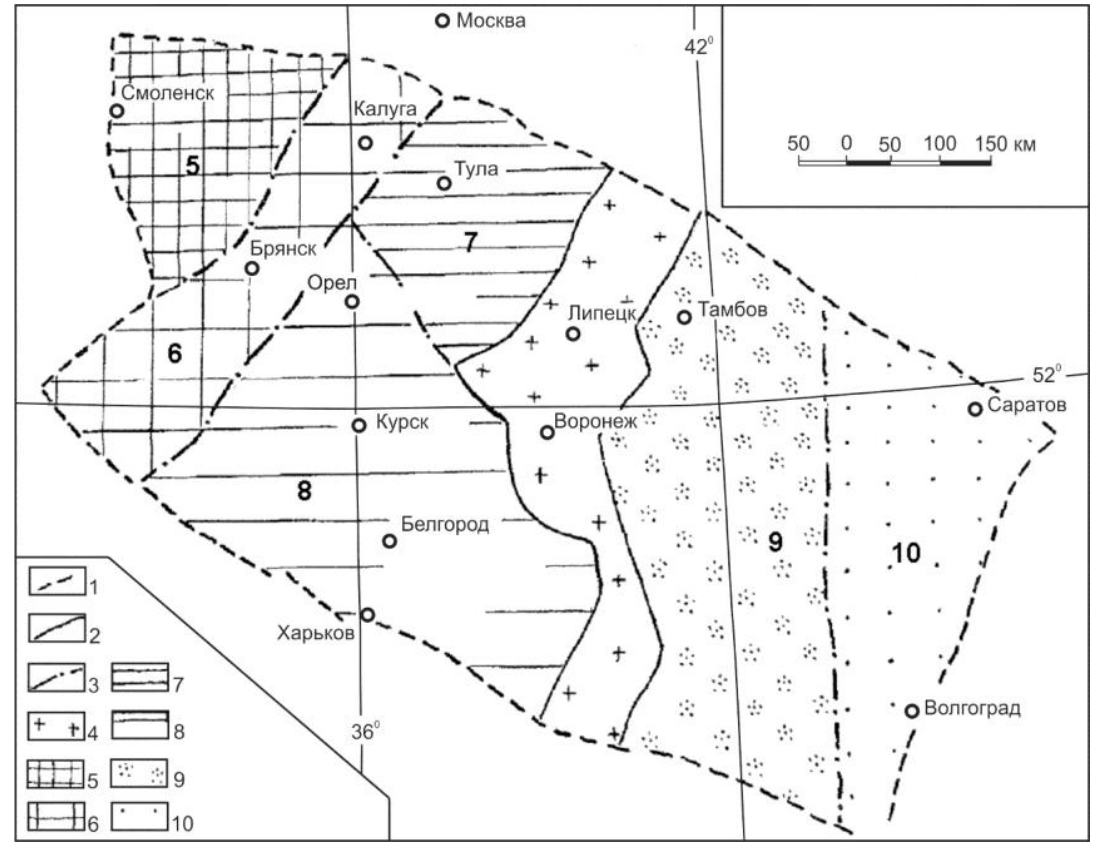

Рис. 1. Схема основных тектонических блоков ВКМ. По И. И. Кривцову, Н. С. Афанасьеву [1]: 1 - границы ВКМ, 2 - границы мегаблоков, 3 - границы макроблоков, 4 - Лосевская (Ливенско-Богучарская) шовная зона сочленения Сарматии и Волго-Уралии. Макроблоки в пределах мегаблока КМА: 5 - Рославльский, 6 - Брянский, 7 - Ливенско-Ефремовский, 8 - Орловско-Курский (Курско-Белгородский). Макроблоки в пределах Хоперского мегаблока: 9 - Калачско-Эртильский, 10 - Камышинский.

[Fig. 1. Scheme of the main tectonic blocks of the VCM. According to I. I. Krivtsov, N. S. Afanasev [1]: 1 - VCM borders, 2 - megablock boundaries, 3 - macroblock borders, 4 - Losevskaya (Livensko-Bogucharskaya) suture joint zone of Sarmatia and Volga-Ural. Macroblocks within the KMA megablock: 5 - Roslavlsky, 6 - Bryansk, 7 - Livensko-Efremovsky, 8 - Oryol-Kursky (Kursk-Belgorod). Macroblocks within the Khopersky megablock: 9 - Kalach-Ertil, 10 - Kamyshinsky.]

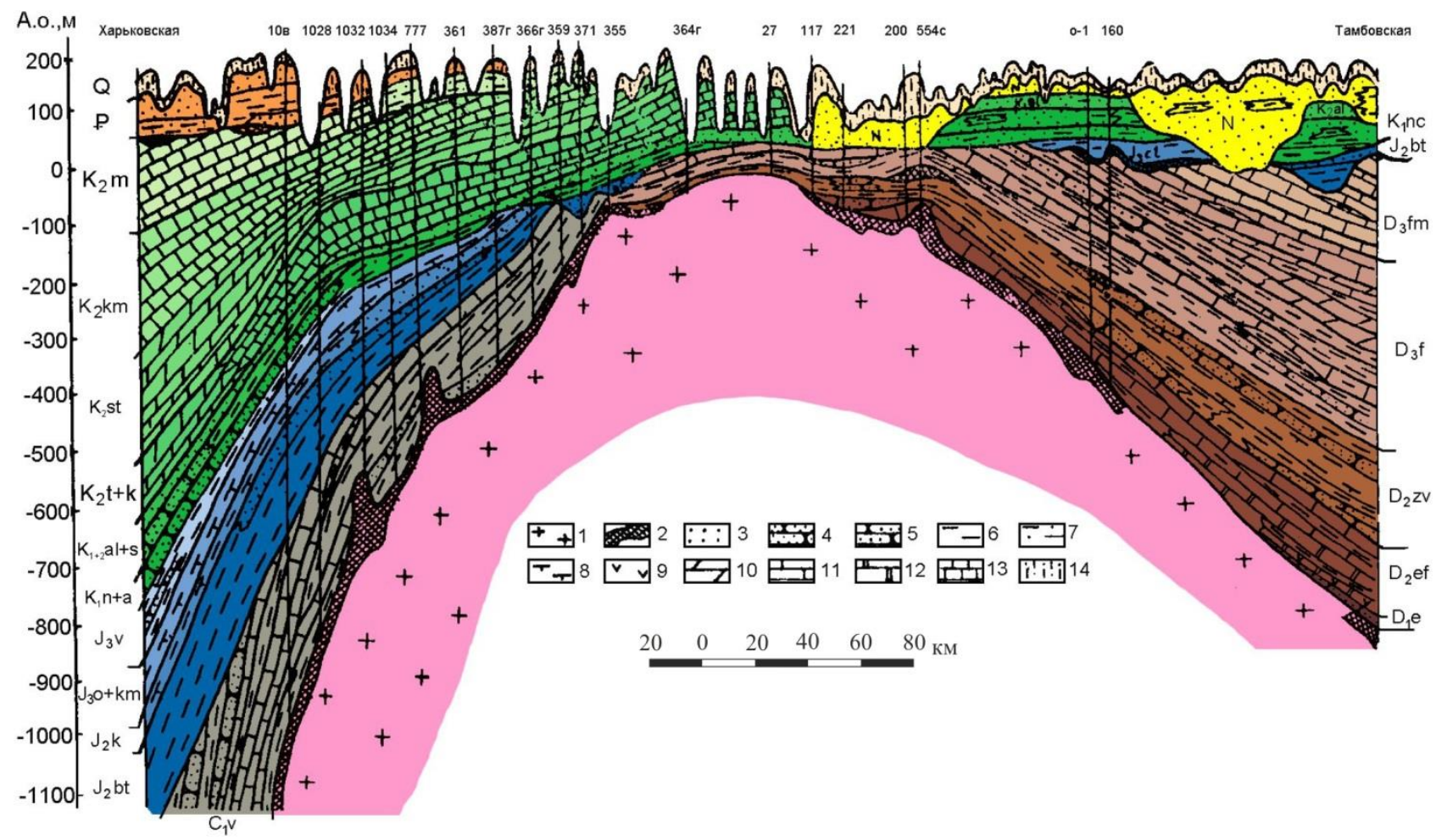

Рис. 2. Разрез осадочных отложений по линии Харьков-Тамбов по [1]: 1 - породы кристаллического фундамента, 2 - кора выветривания, 3 - пески, 4 - песчаники, 5 - алевролиты, 6 - глины, 7 - алевритистые глины, 8 - карбонатные глины, 9 - гипсы и ангидриты, 10 - мергели, 11 - известняки, 12 - доломиты, 13 - мела, 14 - суглинки.

[Fig. 2. Section of sedimentary deposits along the Kharkov-Tambov line, according to [1]: 1 - rocks of the crystalline basement, $2-$ weathering crust, 3 - sands, 4 - sandstones, 5 - siltstone, 6 - clays, 7 - silty clays, 8 - carbonate clays, 9 - gypsum and anhydrite, 10 - marl, 11 - limestones, 12 - dolomites, 13 - chalk, 14 - loam.] 


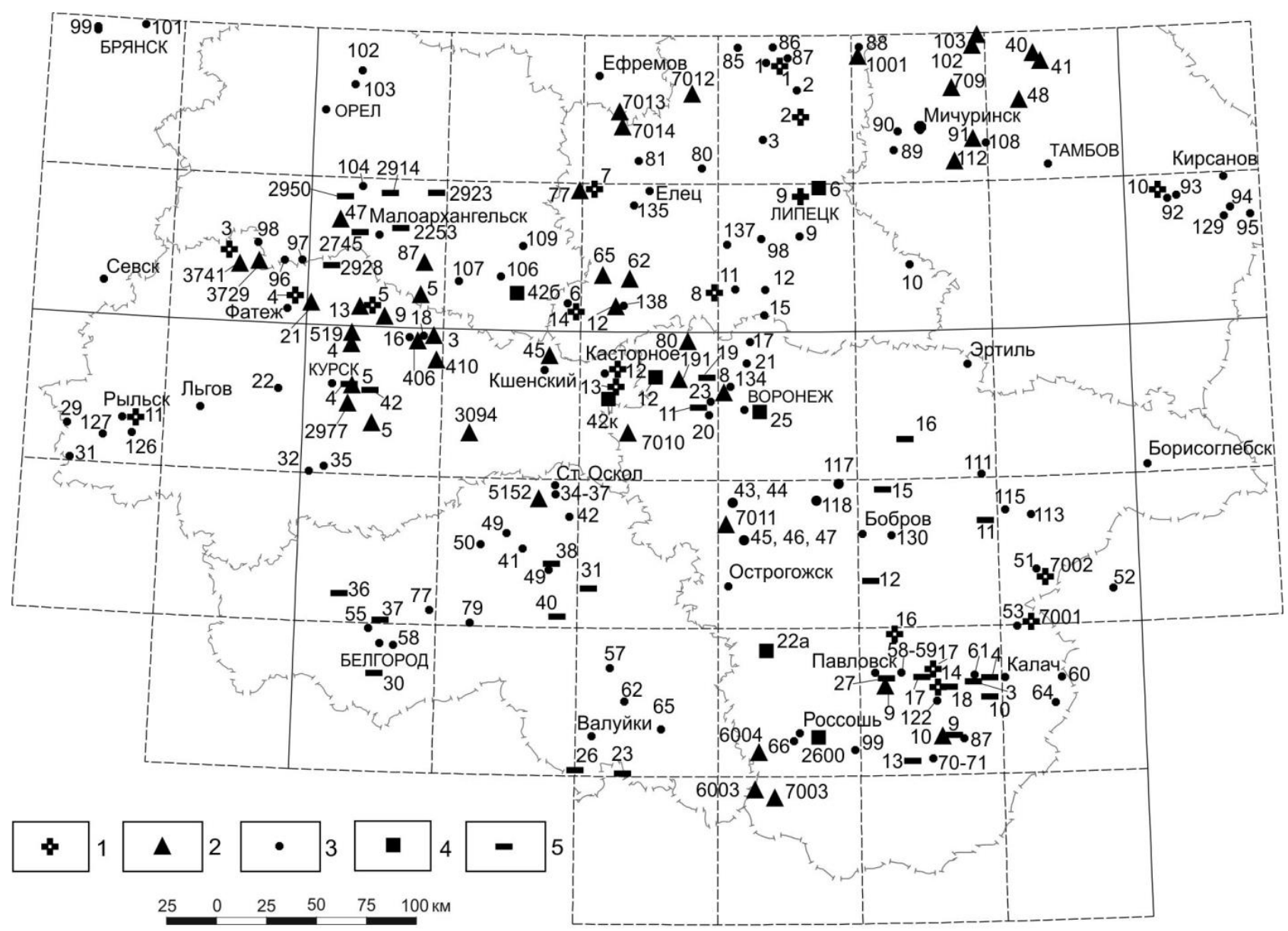

Рис. 3. Карта фактического материала, скважины, т.н. и их номера: 1 - мелкие алмазы, 2 - минералы-индикаторы кимберлитов, 3 -интерметаллиды, 4 - золото, 5 - аномалии полиметаллов.

[Fig. 3. Map of the actual material, wells, watchpoint and their numbers: 1 - small diamonds, 2 - kimberlite indicator minerals, 3 -intermetallic compounds, 4 - gold, 5 - anomalies of polymetals.]

тельные установки ЦВК-100 (помогает в работе с фракциями золота +50 мкм) и малогабаритного комплекса технических средств (МКТС - обогащение в ферромагнитной жидкости, извлечения фракций металла +10-20 мкм) госпредприятия «Грант» (г. НароФоминск). Всего в «Гранте» было выполнено около 150 анализов. В дальнейшем ВГУ получил от «Гранта» центробежный концентратор золота ЦВК-100 и с его помощью обнаружил (аналитик В. В. Ильяш) несколько десятков новых проявлений УТЗ. Однако технологические возможности этой портативной установки не позволяли, в отличие от (МКТС) этой же фирмы, работать с основной массой золота, отчего на первое место в аналитических исследованиях выдвинулась спектрозолотометрия. Золотометрический анализ проб выполнялся в лаборатории ЦНИГРИ, а позднее - в ВГУ (аналитик М. А. Ефремова). В результате в ВГУ был сформирован научный фонд из нескольких тысяч ультратонких золотин, который изучался прецизионными методами.

\section{Результаты исследований}

В предшествующих работах $[1,2]$ выделялись герцинская, киммерийская и альпийская эпохи тектони- ческой активизации территории антеклизы, однако, специфика каждой из них особо не рассматривались, за исключением первой, характеризующейся значительным развитием эксплозивного магматизма. Проведенные авторами настоящей статьи дальнейшее изучение проявлений эндогенных процессов в фанерозое ВА позволили детализировать имеющиеся представления об эпохах эндогенеза и специфику рудогенеза каждой из них. Установлено шесть таких эпох: 1 - раннегерцинская $\left(\mathrm{D}_{2}-\mathrm{C}_{1}\right), 2$ - позднегерцинская $\left(\mathrm{C}_{2}-\mathrm{T}_{1}\right), 3$ - раннекиммерийская $\left(\mathrm{T}_{2}-\mathrm{J}_{1}\right), 4$ - позднекиммерийская $\left(\mathrm{J}_{2}-\mathrm{K}_{1}\right), 5$ - раннеальпийская $\left(\mathrm{K}_{2}-\mathrm{P}_{3}\right)$, 6 - позднеальпийская (N-Q).

Раннегерцинская эпоха является наиболее представительной с точки зрения разнообразия эндогенных пород и руд. В это время по глубинным разломам формировался юго-восточный фланг Воронежской антеклизы и заложилась крупная эрозионно-тектоническая Мамонская депрессия. Она протягивается от Старого Оскола до границ Волгоградской области более чем на 250 км, имеет ширину от первых десятков до 100 км на востоке. Депрессия выполнена песчанокаолиновой толщей, образованной за счет размыва кор выветривания (КВ) на кристаллических породах [3]. 


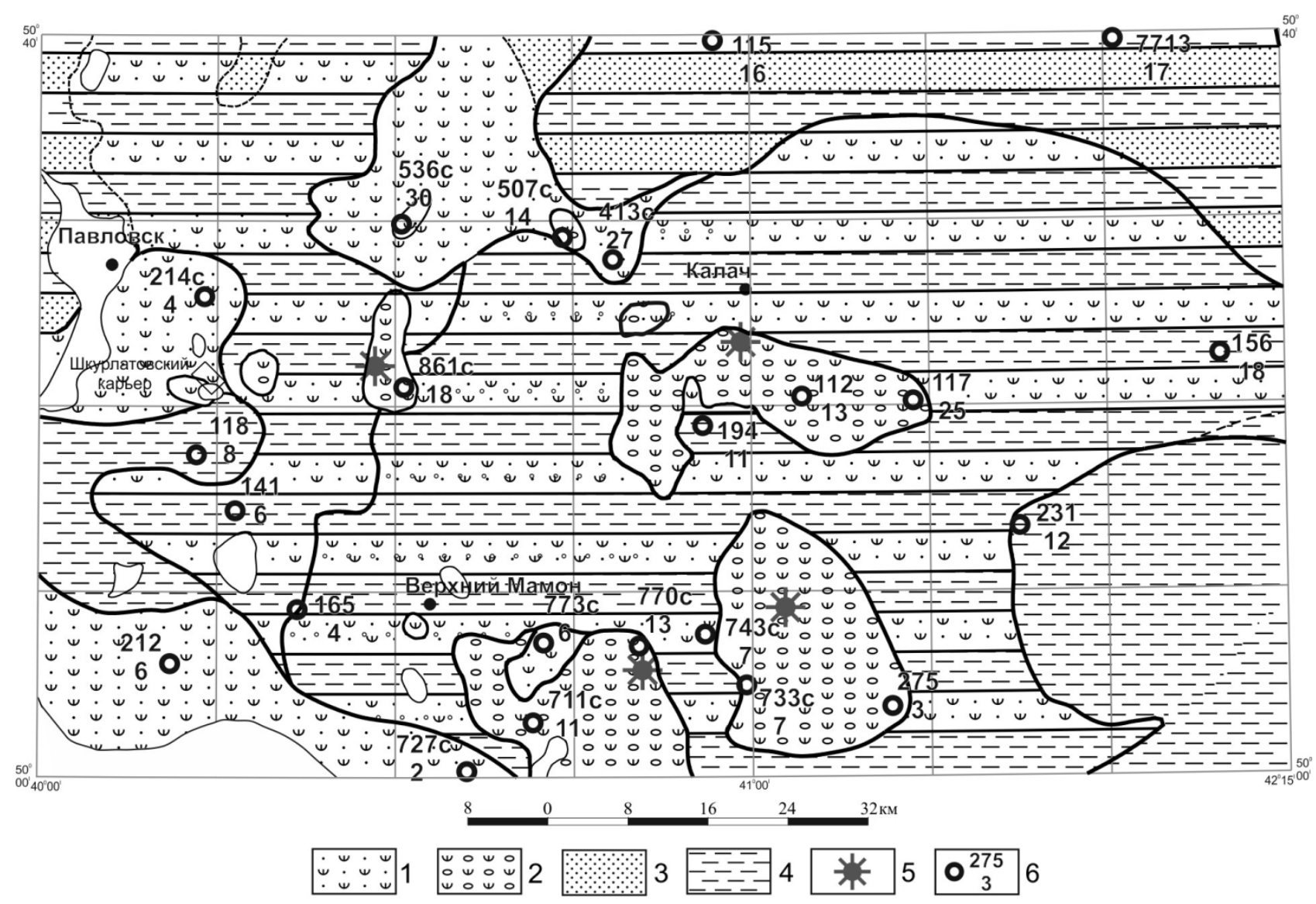

Рис. 4. Литологическая карта ястребовского времени $\left(\mathrm{D}_{3} \mathrm{j} \mathrm{s}\right): 1$ - туфопесчаник; 2 - туфоконгломерат, туфогравелит, часто с прослоями туфов, туффитов, лавобрекчий различного состава; 3 - песчаник; 4 - аргиллитоподобная глина; 5 - предполагаемые жерла вулканических аппаратов; 6 - опорная буровая скважина: в числителе номер скважины, в знаменателе мощность отложений.

[Fig. 4. Lithological map of the yastrebovsky time $\left(\mathrm{D}_{3} \mathrm{j}\right): 1$ - tuff sandstone; 2 - tuffoconglomerate, tuffogravelite, often with interbeds of tuffs, tuffites, breccia of various compositions; 3 - sandstone; 4 - argillite-like clay; 5 - alleged vents of volcanic apparatus; 6 - reference borehole: in the numerator is the number of the well, in the denominator is the thickness of the deposits.]

Образование Воронежской антеклизы сопровождалось неоднократными проявлениями вулканизма. В эйфельское время происходили излияния базальтов в Калужско-Бельской структуре на крайнем севере антеклизы. В начале франского века на юго-востоке региона действовали вулканы (рис. 4), поставляющие в морской бассейн вулканогенный материал [4]. Образовавшиеся вулканогенно-обломочные породы представлены туфами и туффитами, лавобрекчиями различного состава, вулканогенно-осадочные - туфогравелитами, туфопесчаниками, туфоалевритами и туфоаргиллитами. Среди туфов преобладают разности щелочно-базальтового и базальтового состава, гораздо реже встречаются туфы трахириолитов и риолитов. С вулканогенно-осадочными породами связаны ильменитовые россыпи, содержащие до 350 кг/т полезного компонента.

На северо-западе региона свинцово-цинковая минерализация в глинисто-песчаных породах живета, франа и фамена отмечается в зонах трещиноватости (рис. 5), связанных с разломом в поле развития гранито-гнейсовых пород архея.

В начале позднефранского (петинского) времени, в меньшей степени в его конце (евлано-ливенского), произошли излияния толеитовых базальтов (потоковые и жерловые) [5], образовавших несколько полей (рис. 6). Площади их распространения составляют десятки и первые сотни квадратных километров, а мощности пластов от первых до 60 и более метров. В разрезах встречаются слои андезитобазальтов и андезитов, а также разностей с признаками коровой контаминации. Предполагается, что вулканы были центрального и центрально-трещинного типов [6]. Сходные излияния базальтов в франское время были и в пограничной с антеклизой Днепровско-Донецкой впадине [1].

Базальты с размывом залегают на осадочных и вулканогенно-осадочных породах раннего и среднего франа, живета, реже на кристаллических сланцах и базит-гипербазитах докембрия (рис. 7), а перекрываются верхнефранско-фаменскими образованиями песчано-каолиновой толщи [7].

Поля распространения базальтов обычно тяготеют к зонам развития глубинных разломов и располагаются на их пересечениях. С такими долго живущими разломами связаны эксгаляции рудных элементов в породы осадочного чехла. Так, в районе Подколодновского медно-никелевого месторождения (рис. 7) в 


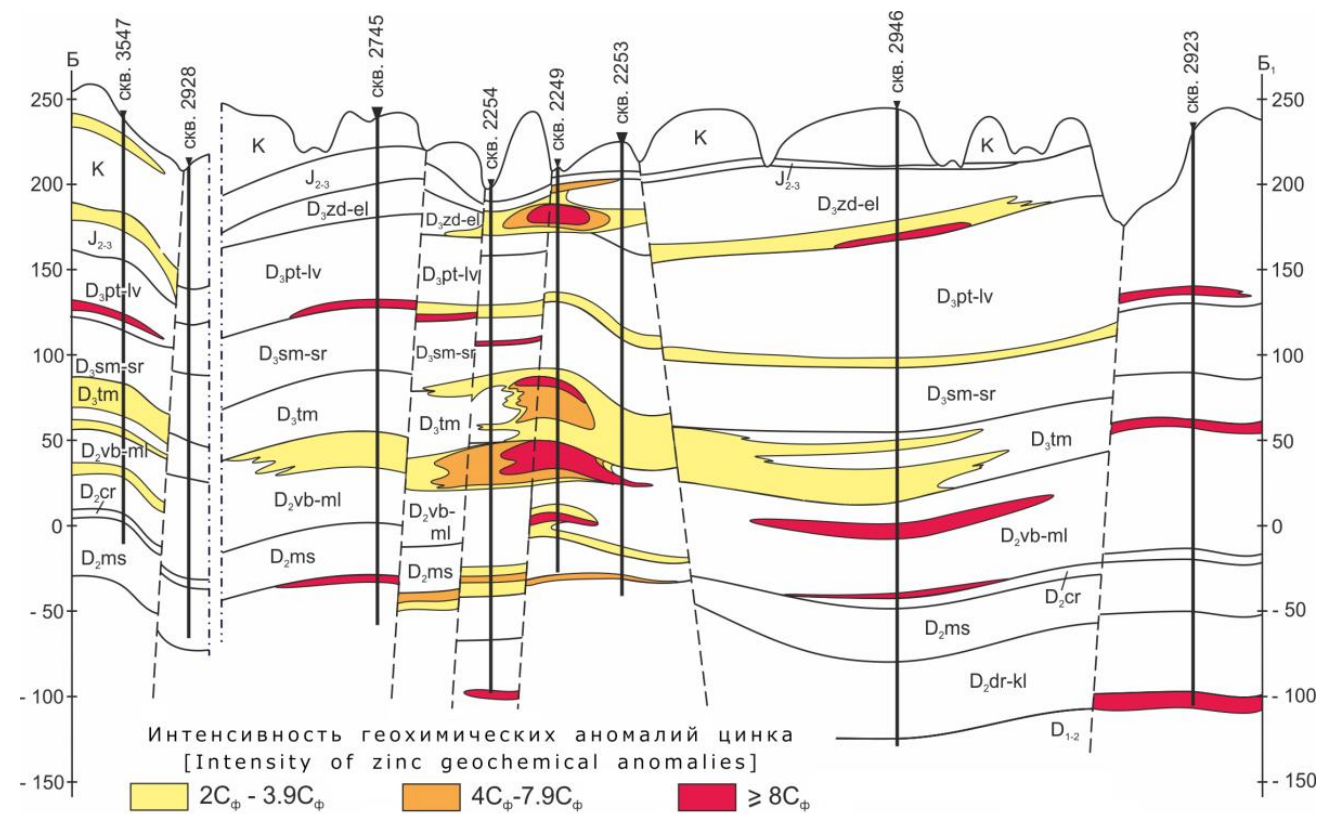

Рис. 5. Свинцово-цинковая минерализация в глинисто-песчаных породах живета и франа: $d r$ - дорогобужская, $k l-$ клинцовская, $m s$ - мосоловская, $c r$ - черноярская, $v b$ - воробъёвская, $t m$ - тимская, $s m$ - семилукская, $s r$ - саргаевская, $p t-$ петинская, $l v-$ ливенская, $z d-$ задонская, $e l$ - елецкая.

[Fig. 5. Lead-zinc mineralization in clay-sandy rocks of zhivet and fran: The Devon Suites: $d r$ - Dorobobuzhaya, $k l-$ Klintsovskaya, $m s$ - Mosolovskaya, $c r$ - Chernoyarskaya, $v b$ - Vorobyovskaya, $t m$ - Timskaya, $s m$ - Semilukskaya, $s r$ - Sargaevskaya, $p t$ - Petinskaya, $l v-$ Livenskaya, $z d$ - Zadonskaya, $e l$ - Eletskaya.]

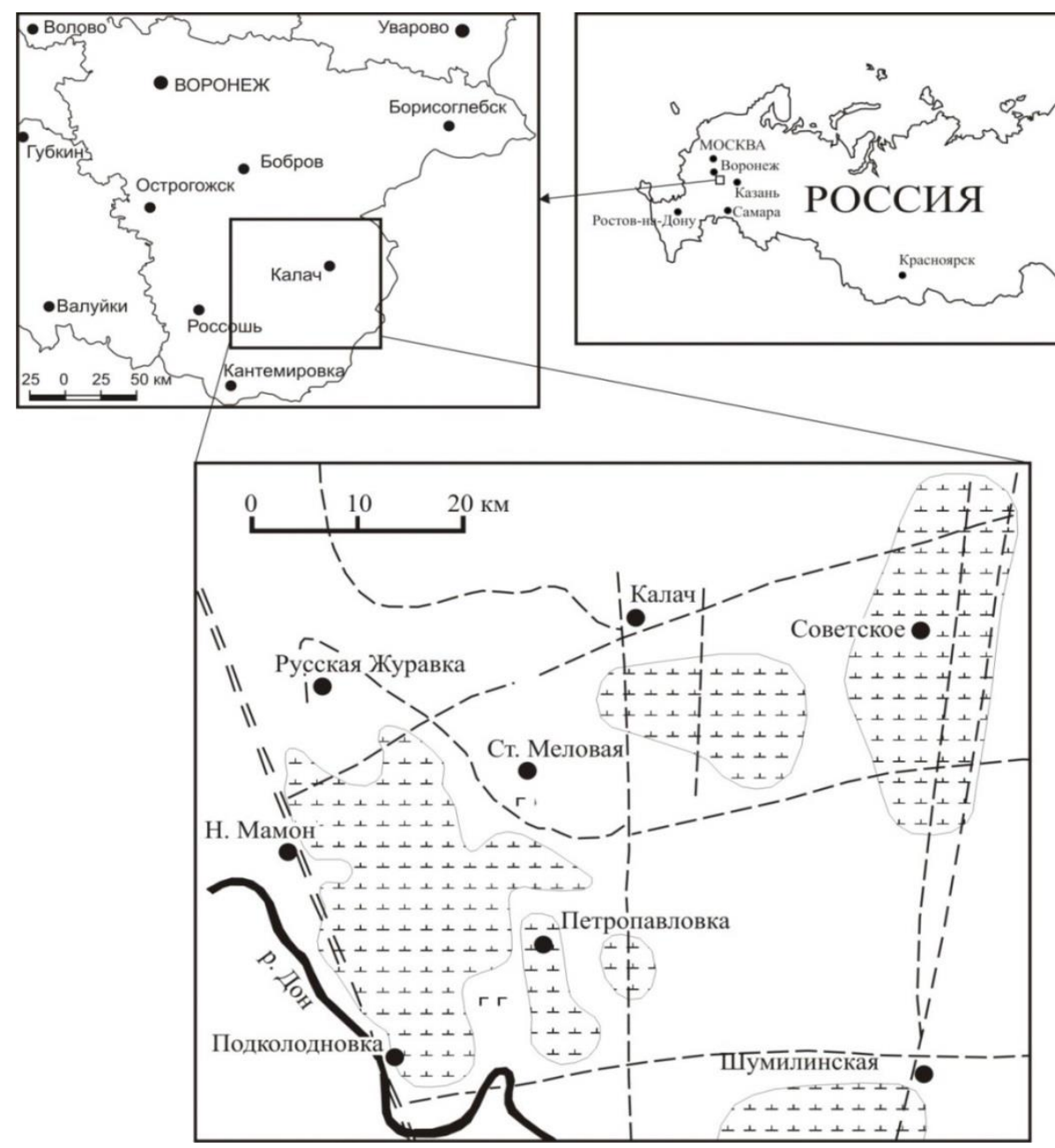

Рис. 6. Поля развития франских базальтов на ЮВ Воронежской антеклизы [5].

[Fig. 6. Fields of development of frasnian basalts in the southeast of the Voronezh anteclise, according to [5].] 


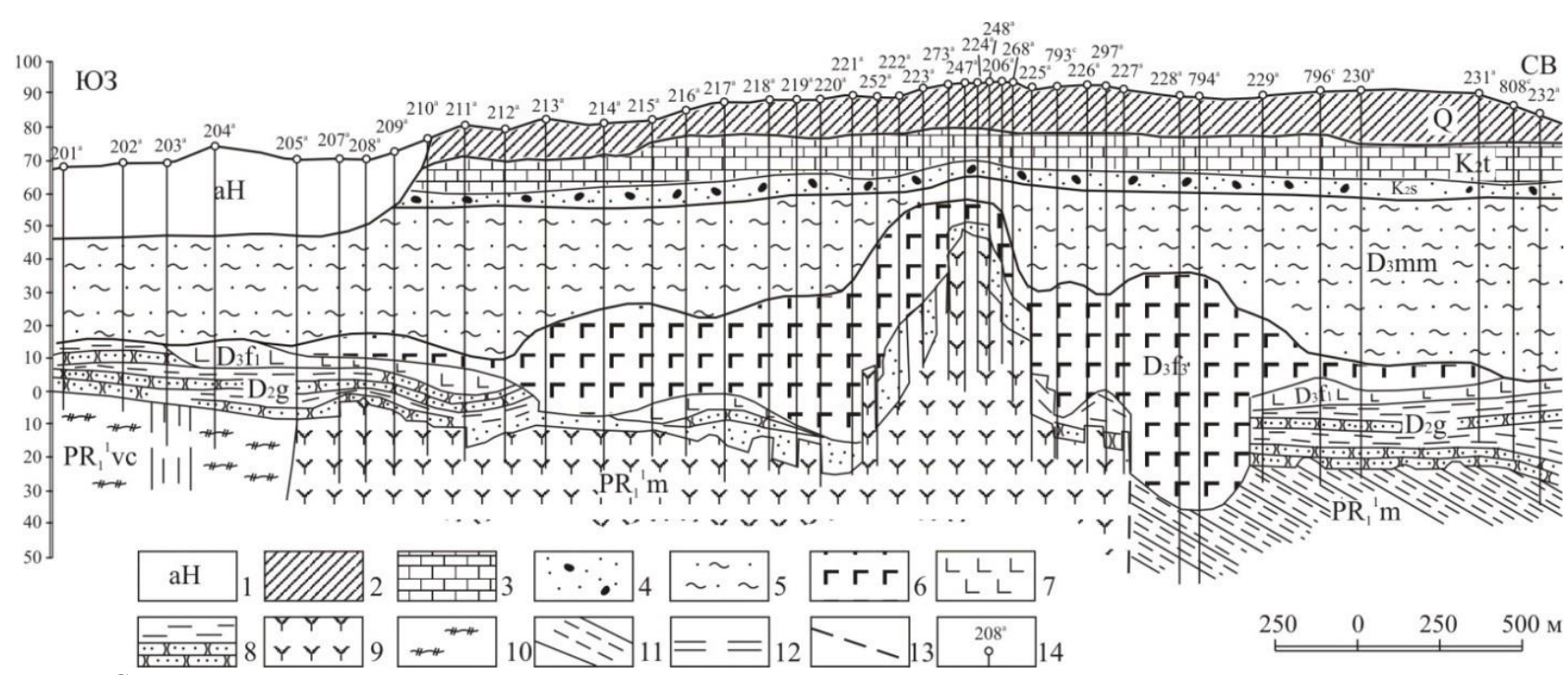

Рис. 7. Схематический геологическиий разрез осадочного чехла района Подколодновского медно-никелевого месторождения: 1 - современный аллювий; 2 - покровные суглинки; 3 - мел $\left(\mathrm{K}_{2} \mathrm{t}\right) ; 4$ - песок с желваками фосфоритов; 5 - песчано-каолиновая толща ( $\left.\mathrm{D}_{3} \mathrm{f}^{3}-\mathrm{fm}\right) ; 6$ - базальты $\left(\mathrm{D}_{3} \mathrm{f}^{3}\right) ; 7$ - туффиты, 8 - песчано-глинистые отложения (D2gv), 9 - ультраосновные породы мамонского комплекса (PR1m); 10-11 вороцовская серия (PR1vc); 12 - Лосевско-Мамонская зона разломов; 13 - линейные зоны разломов; 14 - скважина и ее номер.

[Fig. 7. Schematic geological section of the sedimentary cover of the Podkolodnovsky copper-nickel deposit area: 1 - modern alluvium; 2 - cover loam; 3 - chalk $\left(\mathrm{K}_{2} \mathrm{t}\right) ; 4$ - sand with phosphate rock nodules; 5 - sand-kaolin stratum $\left(\mathrm{D}_{3} \mathrm{f}^{3}-\mathrm{fm}\right) ; 6$ - basalts $\left(\mathrm{D}_{3} \mathrm{f}^{3}\right) ; 7$ - tuffites, 8 - sand-clay deposits (D2gv), 9 - ultrabasic rocks of the Mamon complex (PR1m); 10-11 Vorontsovskaya Series (PR1vc); 12 - LosevskoMamonsky fault zone; 13 - linear zones of faults; 14 - well and its number.]

основании песчано-каолиновой толщи, представленном грубозернистыми песчаниками, отмечается прослой, мощностью до 0.3 м, сцементированный карбонатно-сульфидным веществом [8]. Сульфиды, составляющие 30-35\% объема породы, представлены пиритом (55-60\%), в том числе никелистым (бравоит), халькопиритом (25-30\%) и арсенопиритом (10-12\%). Последний в породе распределен крайне неравномерно. Минералы не только находятся в цементе песчаников, но и образуют тонкие ветвящиеся прожилки.

По данным химических анализов рудных штуфов содержания меди могут достигать 1.0, никеля 0.45 , кобальта $0.04 \%$ [8]. При этом $\mathrm{Cu}$ сосредоточена в халькопирите, Ni в пирите и арсенопирите, Со - в арсенопирите. Эта ассоциация рудных минералов характерна для развитых в этой части антеклизы медноникелевых месторождений в гипербазитах докембрия.

Позднегериинская эпоха отвечает окончательному оформлению Воронежской антеклизы как палеозойской платформенной структуры. Это связано с прогибанием северо-восточного борта ДнепровскоДонецкой впадины (ДДВ), граничащего на северовостоке с антеклизой. В интервал времени пермьтриас происходил размыв и выравнивание территории. Так на большей части антеклизы практически полностью уничтожены каменноугольные отложения, перекрывающие ее полностью в доюрское время. Они сохранились в краевых частях и в опущенном по глубинным разломам небольшом Курско-Бесединском грабене, расположенном в центральной части ВА. В нем (территория листа М-37-I) были изучены каменноугольные образования, отнесенные к визейскому ярусу. В одной из проб, отобранных из разнозернистых песков, установлено наличие сульфидов - сфалерита и галенита. Зерна данных минералов преимущественно неокатанные, в меньшей степени угловатоокатанные, галенит содержится в единичных знаках, сфалерита до 4\% от веса тяжелой фракции.

В скв. 2-г на юго-востоке Воронежской антеклизы, южнее села Новая Меловатка, Р. В. Красненковым обнаружена дайка кварц-полевошпатового состава. Аналогичные образования Приазовья относятся к позднему палеозою, датированы ИМРом (г. Симферополь) в 260-290 \pm 12 млн лет (рубеж ранней и поздней перми). К этому времени, возможно, относятся мощные солевые ореолы меди и никеля, выявленные Г. В. Зеленщиковым на юго-востоке ВА [9]. Один из таких ореолов локализован в девонских породах над интрузией гипербазитов «Липов куст» в пределах Мигулинско-Новохоперской зоны фанерозойской активизации. Соединения $\mathrm{Cu}$, находящиеся в солевой форме, обогащают весь разрез девона. Кроме меди, в сероцветной пачке повышено количество $\mathrm{Ni}-0.7 \times 10^{-2} \%$. Участки с повышенными содержаниями $\mathrm{Cu}$ и $\mathrm{Ni}$, тяготеют к локальному выступу фундамента, и имеют тенденцию расширяться вверх по разрезу. При этом средние содержания элементов почти не меняются, оставаясь близкими в образованиях докембрия и девона.

Содержания меди до $0.5 \%$ в осадочных породах делают интересным этот не вполне обычный тип оруденения. Высокая подвижность элементов обусловлена здесь положением интрузива в пределах зоны фанерозойской активизации с ее многократным раскры- 
тием, интенсивной циркуляцией подземных вод, переносящих рудные компоненты. Все это позволяет по-новому взглянуть на перспективность осадочного чехла над интрузиями гипербазитов ВА, имея в виду возможность открытия в нем рудопроявлений, подобных Шумилинскому.

Из песков и гравелитов базальных горизонтов карбона скв. 4 Курского грабена проанализированы зерна хромшпинелидов. Два анализа на диаграмме Н. В. Соболева $\left(\mathrm{TiO}_{2}-\mathrm{Cr}_{2} \mathrm{O}_{3}\right.$ и $\left.\mathrm{Al}_{2} \mathrm{O}_{3}-\mathrm{Cr}_{2} \mathrm{O}_{3}\right)$ попали в поле составов алмазной ассоциации. На диаграмме Фипке $\left(\mathrm{MgO}-\mathrm{Cr}_{2} \mathrm{O}_{3}\right)$, результаты одного анализа разместились в поле алмазоносных кимберлитов [10]. Это первая и потому особенно ценная находка из столь древней осадочной толщи региона. На диаграмме В. И. Ваганова $\left(\mathrm{Fe}^{3+} /\left(\mathrm{Fe}^{3+}+\mathrm{Al}+\mathrm{Cr}\right)\right.$ одна точка (проба 4/198) оказалась на пересечении полей алмазоносных и неалмазоносных кимберлитов.

Раннекиммерийская эпоха характеризуется широким проявлением эндогенных процессов на большей части ВА. В ее пределах выделены следующие минерагенические районы, в пределах которых известны проявления киммерийского рудогенеза (рис. 8): 1 Белгородско-Миллеровский, 2 - Курский, 3 - Восточно-Воронежский, 4 - Брянско-Орловский [11]. Районы с оруденением в осадочном чехле занимают краевые части антеклизы, тяготеют к зонам активизации. Курский район, расположенный на своде, имеет рудопроявления только в активизированных участках фундамента. Для площади с наиболее активными геодинамическими процессами (Восточно-Воронежский район) выявлены максимальные концентрации проявлений эндогенных полезных ископаемых (см. рис. 8).

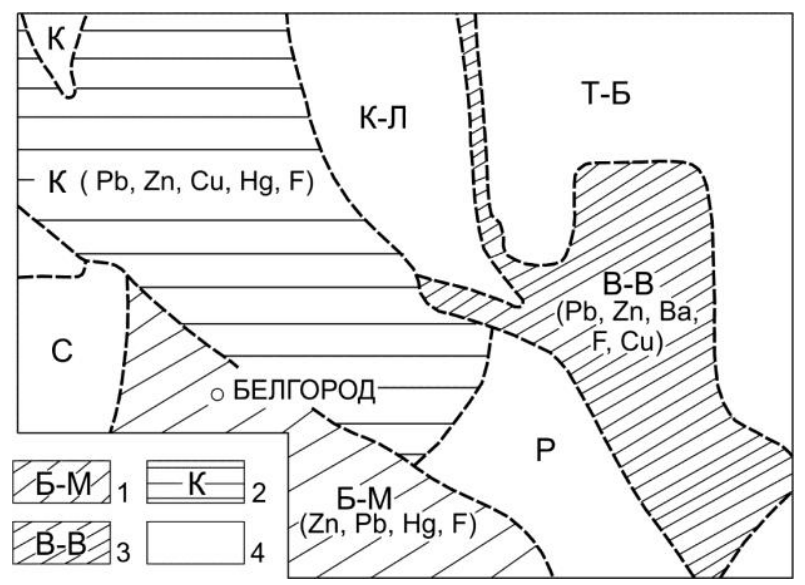

Рис. 8. Минерагеническое районирование осадочного чехла Воронежской антеклизы. Минерагенические районы: 1 . Белгородско-Миллеровский (полиметаллы, флюорит) - Б-М; 2. Курский (каменные строительные материалы, полиметаллы, ртуть, флюорит в породах докембрия) - К; 3. ВосточноВоронежский (полиметаллы, медь, барит, флюорит, каменные строительные материалы) - В-В; 4. Бесперспективные площади срединных массивов и районов с неблагоприятной тектонофизической обстановкой: Карачевская (К), Сумская (С), Россошанская (Р), Касторненско-Ливенская (К-Л), ТамбовскоБорисоглебская (Т-Б). Эти площади представляют, однако, интерес при прогнозировании кимберлитов [1].
[Fig. 8. Mineralic zoning of the sedimentary cover of the Voronezh anteclise. Mineragenic areas: 1. Belgorod-Millerovsky (polymetals, fluorite) - B-M; 2. Kursky (stone building materials, polymetals, mercury, fluorite in Precambrian rocks) - K; 3. East Voronezh (polymetals, copper, barite, fluorite, stone building materials) - V-V; 4. Unpromising areas of middle massifs and regions with unfavorable tectonophysical conditions: Karachevskaya (K), Sumy (C), Rossoshanskaya (R), Kastornensko-Livenskaya (K-L), Tambov-Borisoglebskaya (T-B). These areas are, however, of interest in predicting kimberlites [1].]

Рудные тела тяготеют к зонам тектонических нарушений высоких порядков и расположены в пределах Белгородско-Марковской зоны. Цепочки рудопроявлений прослежены до границы Белгородской области в соседних районах Украины работами ПГО «Луганскгеология», они описаны в работе [12]. Такие проявления известны в Белгородском районе, где перспективы обнаружения рудных тел не ниже, чем на Украине, так как в структурном отношении эти площади едины, мощности же осадочного чехла на КМА меньше. Белгородско-Миллеровский минерагенический район - это продолженный на северо-запад Старобельско-Милллеровский район в понимании Е. Г. Сущука [13]. Установлены следующие особенности местных рудопроявлений:

1 - приуроченность к нижне-, и среднекаменноугольным отложениям на площади несколько тыс. км² при глубинах 250-400 м;

2 - смещение оруденения вверх по разрезу «от намюра в районе с. Марковка до башкирского яруса в районе сел Белолуцкое и Вейделевка». Проявления представляют собой сфалерит-флюоритовые прожилки в нижневизейской терригенной толще мощностью 0.5-1.0 см, «секущие кальцитизированные магнезиально-сидеритовые конкреции»;

3 - выделяются три типа оруденения: a - прожилково-вкрапленных руд с мощностью рудоносных тел до 60 м и больше и содержаниями $\mathrm{Zn}$ до $1.12 \%, \mathrm{~Pb}-$ до $0.35 \%$; б - метасоматические линзообразные залежи в зонах развития выщелоченных и брекчированных пород. Там количество сульфидов полиметаллов достигает $50 \%$ от их объема, в т.ч. $\mathrm{Zn}$ - до $3 \%$ и более, $\mathrm{Pb}$ - до $0.5 \%$; в - жильный, в виде халцедонкарбонатных и карбонатных жил с вкрапленностью сульфидов;

4 - минеральный состав руд: пирит, сфалерит, реже галенит, а также халькопирит, арсенопирит, марказит, киноварь, антимонит. Нерудные минералы представлены кварцем, халцедоном, доломитом, кальцитом, баритом, флюоритом, с примесью битумов. Концентрация рудных элементов достигает промышленных значений: $\mathrm{Cu}$ - до $0.1 \%, \mathrm{~Pb}$ - до $1.5 \%, \mathrm{Zn}$ - от 3 до $12 \%$;

5 - возраст оруденения, определенный по галениту, 200 \pm 30 млн лет [12];

6 - изотопный анализ серы показал, что ее минералы образовались в результате сульфат-редукции в бескислородных закрытых системах;

7 - положение наиболее крупных рудопроявлений 
контролируют субмеридиональные разрывы, пересекающие Белгородско-Марковскую зону;

8 - гидротермальный тип рудного вещества, показанный ранее Е. М. Крестиным, Ю. А. Шустовым и Ю. А. Егоровым, с температурами декрепитации кальцитов: $80-120^{\circ}$ (редко $140^{\circ}$ ), 160 и 180-200 массовым растрескиванием при $220-260^{\circ} \mathrm{C}$;

9 - руды располагаются лишь в доломитизированных известняках. «Там, где каменноугольные известняки... не доломитизированы, руды нет», писали Г. Ф. Багно и В. Н. Машир [14]. Проявления полиметаллов на юго-западе тяготеют к периферии Россошанского срединного массива (рис. 8), где располагались площади разгрузки тектонических напряжений. Источник последних - Днепровско-Донецкая впадина. Сходной структурной позицией обладает плохо изученная бурением часть Белгородско-Марковской зоны, прилегающей к Сумскому массиву.

На территории листа N-37-XXXI (Малоархангельск) практически во всех стратиграфических горизонтах выделяются аномалии цинка. Наиболее интенсивные и мощные из них приурочены к границе среднего и нижнего девона. Максимальные содержания цинка установлены в скважинах 2950 $0.1 \%$ и $2745-0.3 \%$ (рис. 3). Южнее этих аномалий в юрских отложениях, в глинах батского яруса, были установлены содержания Zn до $0.85 \%$, Ge и U 340 и 51.4 г/т соответственно.

В пределах листа М-37-III (Касторное) скважиной № 11, расположенной вблизи с. Еманча 1-я, по данным ПКСА были установлены аномальные содержания цинка. Они отмечаются в глинах и алевритах воронежской свиты. В них отмечаются вкрапления марказита и гипса. Максимальные концен- трации приурочены к кровле слоя, к контакту воронежских глин с песками готерив-барремского возраста, где Zn 1\%, вниз по разрезу его концентрация падает до $0.3 \%$.

В северо-восточной стенке Михайловского карьера под г. Железногорском Курской области вскрыто основание нижнебатских прибрежно-морских тонких песков с редкой галькой кремня. Из них были выделены микрокристаллы алмаза (рис. 9). Они обнаружены в 5 образцах, отобранных по керну скважин, и из одной пробы из уступа восточного борта карьера. Количество мелких алмазов в изученных образцах от 1 до 29 знаков, всего выделено 39 зерен. Встречен один обломок фиолетового пиропа $0.5 \times 0.2 \times 0.1$ мм, редкие зерна пикроильменита. Поступили они в морской бассейн из области суши, занимавшей в байосе - раннем бате всю центральную часть антеклизы.

В районе г. Курска МИК найдены в песчаных отложениях келловея (скв. 5). Из пробы весом 8 кг было получено одно зерно хромшпинелида, размером 0.25 мм (рис. 7). Оно представлено гладкогранным комбинационным кристаллом, для которого характерна гипергенно-механогенная поверхность. Содержания основных оксидов: $\mathrm{Cr}_{2} \mathrm{O}_{3}-57.29, \mathrm{FeO}-31.53, \mathrm{Al}_{2} \mathrm{O}_{3}-$ 6.26, $\mathrm{MgO}-1.85, \mathrm{TiO}_{2}-0.06$ мас. \%.

На северо-востоке антеклизы (Тамбовская область) в юрских отложениях келловея из пробы 102/91 (скв. 102) выделено 27 знаков хромшпинелидов. Они характеризуются близкой степенью окатанности (2-3 класс) и однотипным характером поверхности с признаками гипергенного преобразования. Содержание $\mathrm{Cr}_{2} \mathrm{O}_{3}$ от 46.5 до 56.66, $\mathrm{FeO}$ от 25.18 до $34.27, \mathrm{Al}_{2} \mathrm{O}_{3}$ от 7.31 до $10.03, \mathrm{MgO}$ от 6.58 до 9.41, $\mathrm{TiO}_{2}$ от 0.28 до $0.61 \%$.

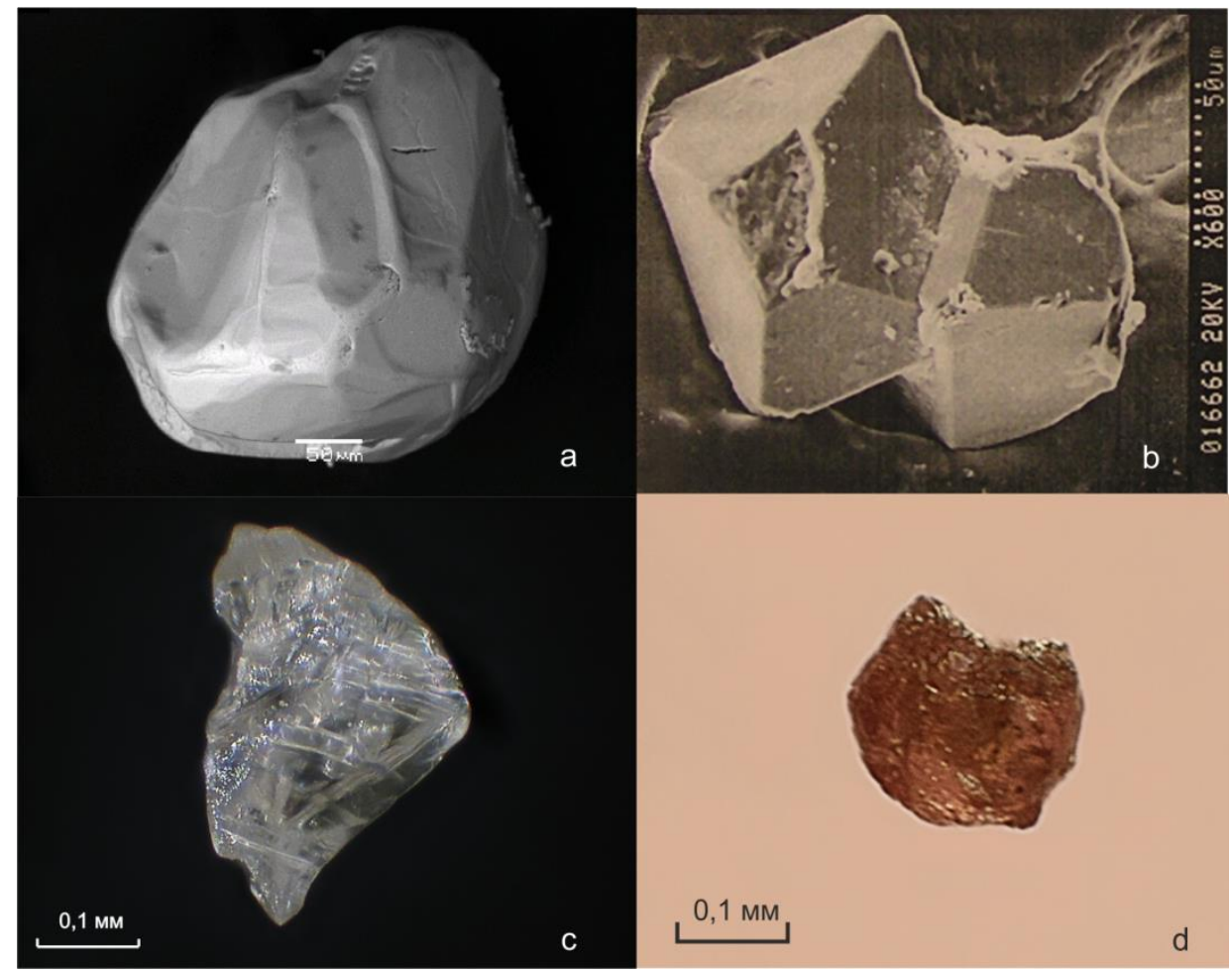

Рис. 9. Минералы индикаторы кимберлитов: $a-$ комбинационный кристалл хромшпинелида, скв. $5 ; b-$ микрокристаллы алмаза из Михайловского карьера; $c$ - $d-$ алмазы из местонахождения Верхняя Колыбелька.

[Fig. 9. Minerals, indicators of kimberlites: $a$ - combination crystal of chrome spinel, borehole. $5 ; b$ - diamond microcrystals from the Mikhailovsky quarry; $c-d$ - diamonds from the Verkhnyaya Kolybelka location.] 
Позднекиммерийская эпоха. В северной части ВА в базальных горизонтах неокома, аптского, альбского и сеноманского ярусов встречено значительное количество минералогических свидетельств вулканических эксплозий, которые считаются мезозойскими (позднеюрскими-раннемеловыми). Сюда относятся длиннопризматические цирконы Слободки на реке Птань (аптские отложения севера Липецкой области), псевдоморфозы сульфидов по вулканическим стеклам в тяжелой фракции отдельных проб. С предполагаемым мезозойским магматизмом связаны многочисленные находки мелких алмазов в меловых песках. Еще в 1969 г. в аптских алевритах Липецкой области (Волчинская титан-циркониевая россыпь) в одной из проб Ю. А. Полкановым и Н. Ф. Кашкаровым встречено 241 зерно алмазов размером от 0.15-0.25 мм до 0.34 мм, средним весом 10 мг, содержанием 0.0268 карата/м ${ }^{3}$. Ими же были открыты 17 кристаллов алмаза в сеноманских мелкозернистых песках Центрального титан-циркониевого месторождения Тамбовской области. В 2002 г. из проб, отобранных сотрудниками ВГУ и обогащенных в ИМРе (г. Симферополь), из- влечено около 100 мелких алмазов. Особенностью минеральных ассоциаций является практическое отсутствие в них минералов-спутников алмазов (МСА), что характерно для алмазоносных лампроитов. Возможно, позднекиммерийская эпоха алмазоносности в регионе отличалась по этому признаку от раннегерцинской, проявившейся на Белорусской антеклизе и Приазовском массиве.

В песчаных породах неокома, апта и альба, в меньшей степени сеномана из крупнообъемных проб

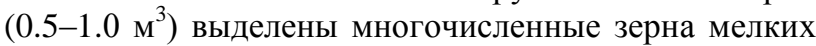
алмазов и их минералов-индикаторов (пиропы, хромшпинелиды, пикроильмениты) (рис. 10, 11). Количество алмазов в одной пробе может достигать первых сотен. В ассоциациях неокомских проб преобладают минералы-индикаторов кимберлитов (МИК), в аптских и альбских присутствуют МИК и алмазы. Аптский и альбский коллектора являются самыми продуктивными на обнаружение МИК не только внутри мелового коллектора, но и среди других образований рассматриваемой территории [15]. В сеноманских песках, как и неокомских, преобладают МИК.

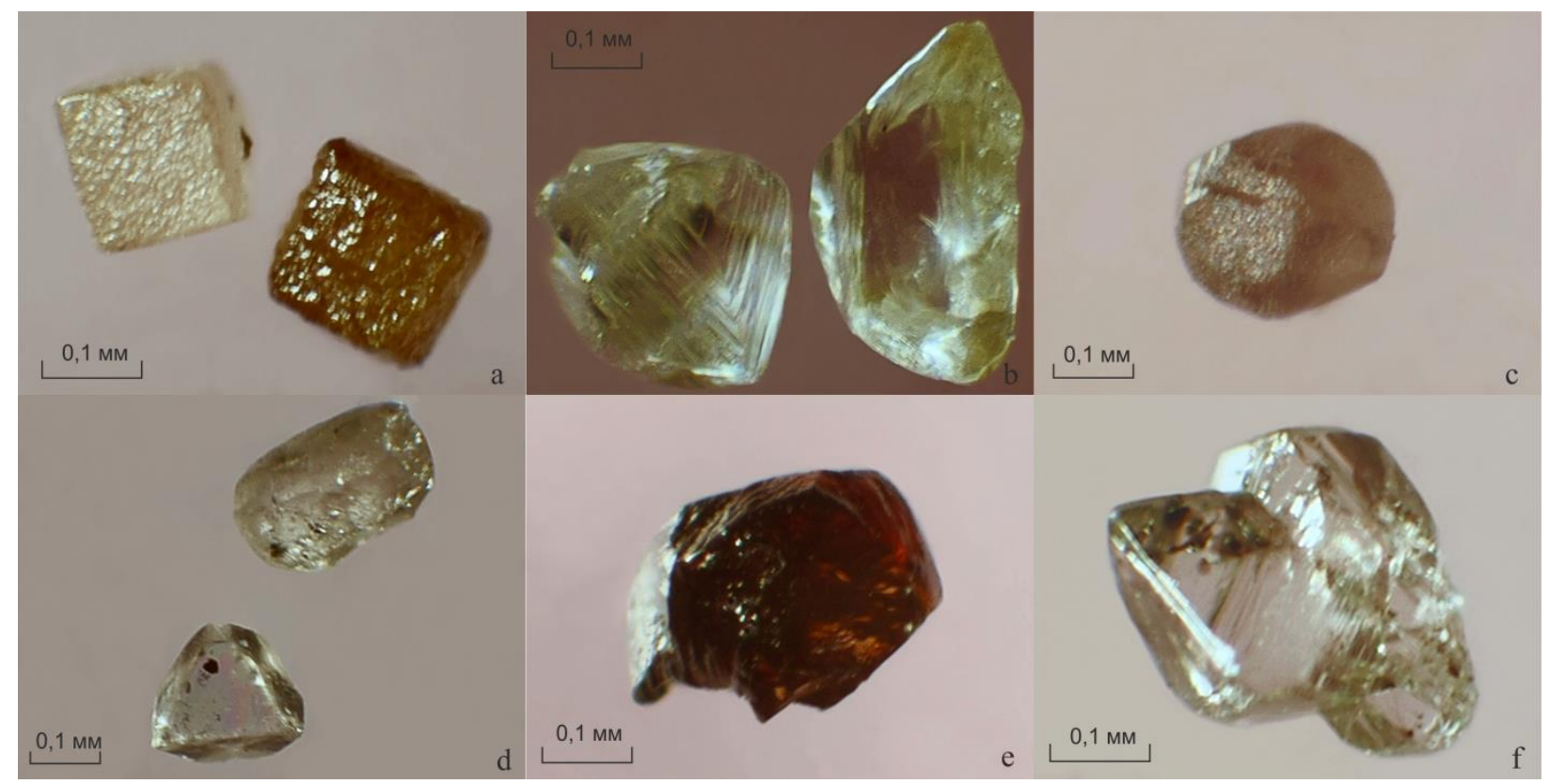

Рис. 10. Алмазы аптского возраста из Волчинской россыпи: $a$ - два кристалла кубической формы; $b-$ октаэдры; $c$ - кубоктаэдр; $d$ - октаэдр и зерно эллипсовидной формы; $e$ - ромбододекаэдроид; $f$ - сростки октаэдров.

[Fig. 10. Diamonds of aptian age from the volchinsky placer: $a$-two crystals of cubic form; $b$ - octahedrons; $c$-is the cubic octahedron; $d$ - octahedron and grain of ellipsoidal shape; $e$ - is a rhombic dodecahedroid; $f$-intergrowths of octahedra.]

Раннеальпийская эпоха. Проявления этой эпохи распространены на территории, расположенной восточнее Россошанского массива и особенно в Богучарско-Ливенской зоне. Рассматриваемая зона находится в пределах влияния Доно-Медведицкого авлакогена, активного на альпийском и неотектоническом этапах, что сказалось на облике и возрасте рудопроявлений.

Наиболее выраженное из них локализовано в туронском писчем мелу Шкурлатовского рудного поля. Гнезда рыжих охр со скоплениями барита и сфалерита там наблюдались близ протрузии граносиенитов.
Они имели диаметр 0.1-0.3 м и группировались в полосу шириной 3-5 м. Барит отличался копьевидным обликом кристаллов от разновидностей этого минерала в девонском карбонатном метасоматите. Проявление в писчем мелу пока единственное на антеклизе, уверенно относится к альпийскому этапу рудогенеза. Более точный его возраст пока установить невозможно. Единственным мощным экраном, залегающим выше писчего мела, являются гаврильские (верхневалдайские) глины. Вне площади их распространения оруденения в писчих мелах нет. 


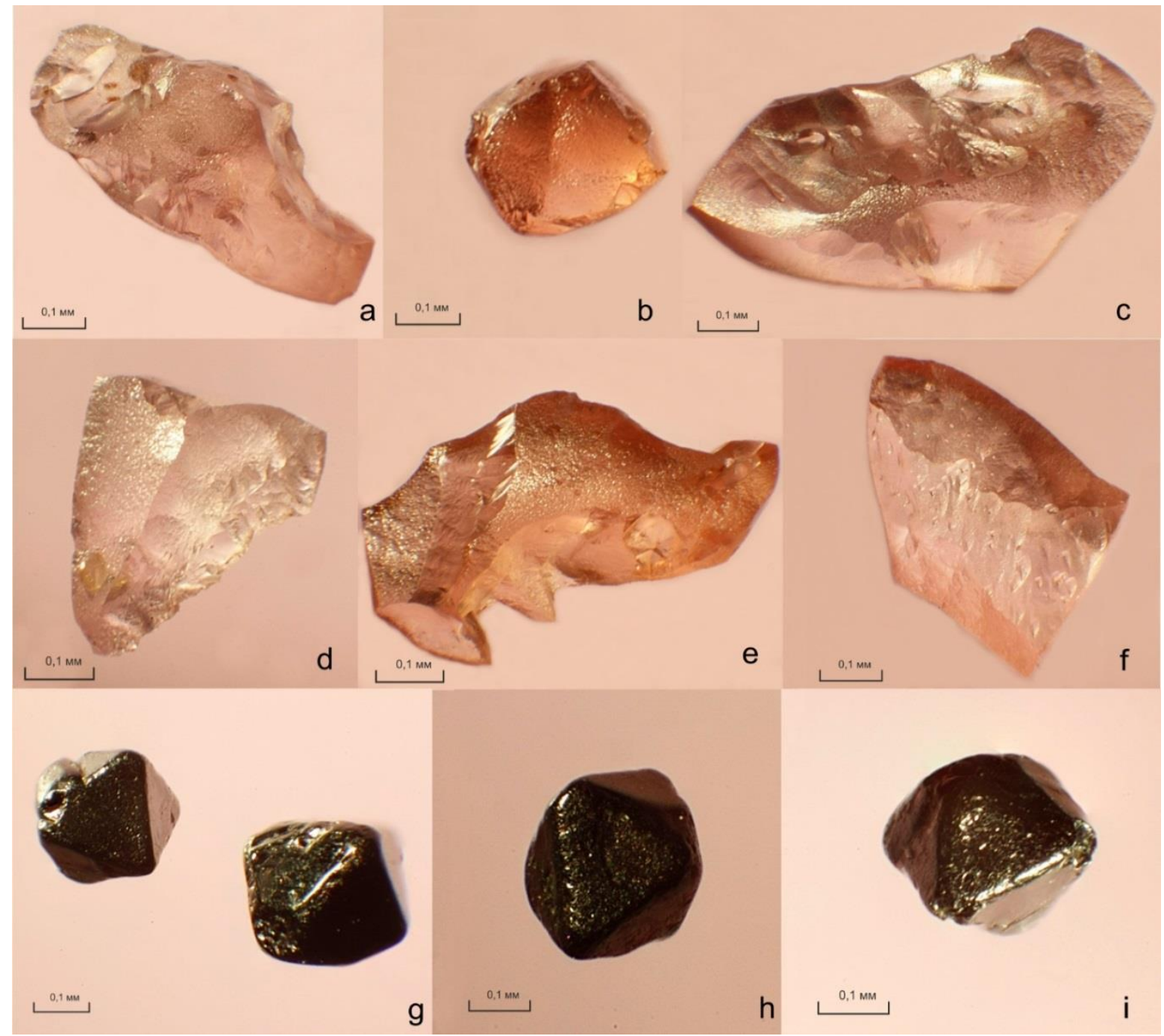

Рис. 11. Морфологические особенности пиропов и хромшпинелидов из альбских песков: $a-f-$ пиропы с гипергенной и гипергенно-механогенной поверхностью; $g$ - $i$ - хромшпинелиды.

[Fig. 11. Morphological features of pyropes and chrome spinels from albian sands: $a-f$-pyropes with a hypergenic and hypergenicmechanogenic surface; $g-i$ - chrome spinels.]

Основную часть Шкурлатовского проявления (рис. 12) образуют пластообразные тела рудоносных карбонатных метасоматитов, кораллового биогерма, анкеритизированного, мощностью $0.6-0.8$ м, в раздувах до 1.5 м. Многочисленные пустоты выщелачивания в нем рассеяны неравномерно и тяготеют к участкам максимального развития колоний кораллов. Преобладают их уплощенные горизонтальные системы сложных очертаний размером 3-10 см. Самые крупные пустоты соединяются узкими извилистыми каналами. Степень каверзности 0.05-0.1, на отдельных участках 0.2-0.3. Рудная минерализация наблюдалась в $60 \%$ полостей и вдоль трубок кораллитов. Она представлена корочками, агрегатами кристаллов, редко прожилками сфалерита, халькопирита, барита, пирита, олигонита, выстилающих поверхность каверн. Стадийность отложения минералов: пирит (пентагондодекаэдры)сфалерит-барит. В безрудную стадию образовался кальцит в виде корочек толщиной 1-8 мм.

Сфалерит встречен в виде кристаллов размером до
6-8 мм, агрегатов, сплошных масс, выполняющих каверны. Его кристаллы - это в различной степени уплощенные тетраэдры \{III\}, сгруппированные в изометричные гроздевидные агрегаты. Рефлексы выражены при большом (х200) увеличении, они красные (у типичного сфалерита желтые). Несколько необычные свойства минерала объясняются большим количеством примесей. По данным лаборатории ИМРа (Симферополь), отмечаются $\mathrm{Si}(4 \%), \mathrm{Fe}(2 \%), \mathrm{Al}$ (0.8\%), Ca (1.2\%), Cd (0.5\%), Pb (0.5\%), Ti (0.06\%), In (0.032\%), $\mathrm{Cu}(0.05 \%), \mathrm{Mn}(0.032 \%), \mathrm{Ni}(0.003 \%), \mathrm{Co}$ $(0.001 \%), \operatorname{Sn}(0.005 \%)$ и $\mathrm{Ga}(0.004 \%)$.

Барит (рис. 13, а) образует серо-голубые пластинчатые кристаллы размером от 1 до $4.5 \mathrm{~cm}$, одиночные и сложные сростки. Наиболее часто встречаются формы в виде комбинации пинакоида $\{001\}$. Кристаллы содержат тонкую эмульсионную взвесь марматита. В минерале встречены (мас. \%): $\mathrm{Sr}-0.15, \mathrm{Al}$ $-0.8, \mathrm{Ca}-3.2, \mathrm{Fe}-10, \mathrm{Si}-3.2, \mathrm{Mg}-1.0, \mathrm{Zn}-0.04$, $\mathrm{Na}-0.063$. 


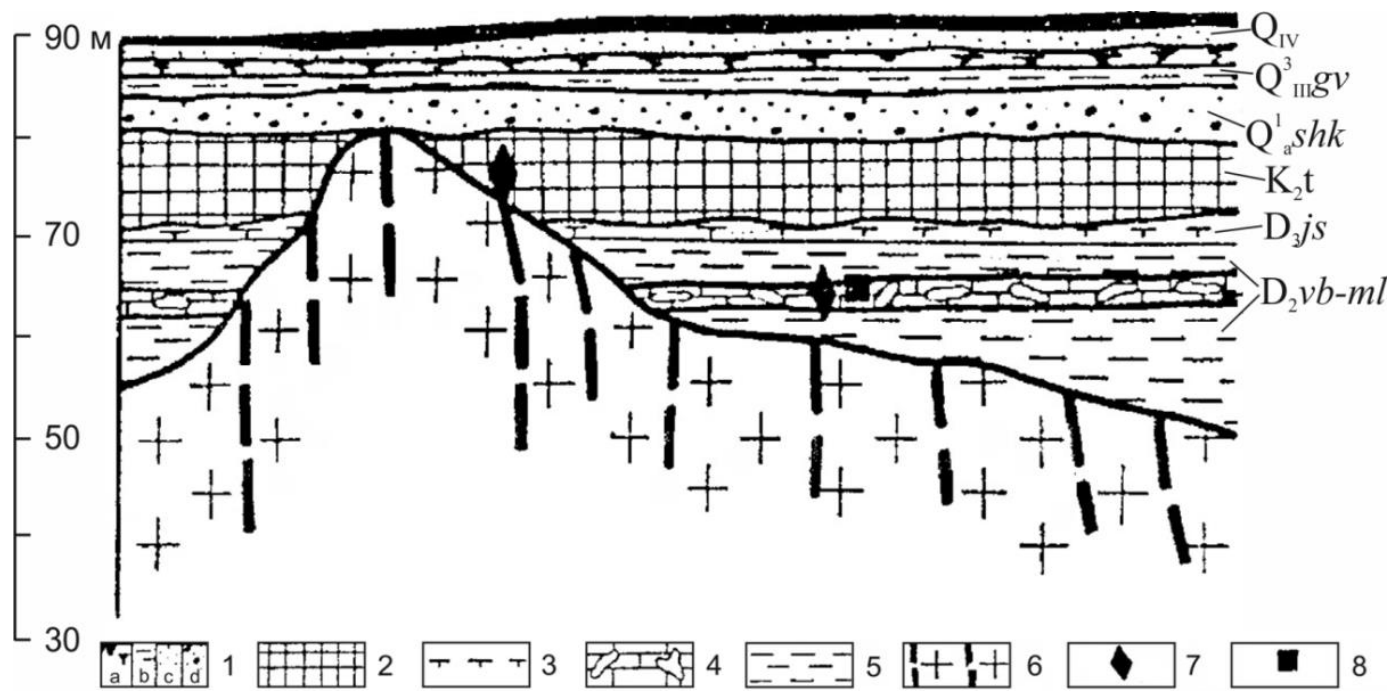

Рис. 12. Шкурлатовское барит-полиметалическое рудопроявление: 1 - палеопочва (a), суглинки (b), алевриты (c), гравийные пески (d); 2 - писчий мел; 3 - туффиты; 4 - анкеритит; 5 - аргиллиты; 6 - граносиениты; 7 - барит; 8 - полиметаллы. Названия свит: $g v$ - гаврильская, $s h k$ - шкурлатская, $j s$ - ястребовская, $v b$ - воробъёвская, $m l$ - муллинская.

[Fig. 12. Shkurlatovsky barite-polymetallic ore occurrence: 1 - paleosol (a), loam (b), siltstone (c), gravel sands (d); 2 - writing chalk; 3 - tuffits; 4 - ankeritis; 5 - mudstones; 6 - granosyenites; 7 - barite; 8 - polymetals. The names of the suites: gv - Gavrilskaya, shkShkurlatskaya, $j s$ - Yastrebovskaya, $v b$ - Vorobyovskaya, $m l$ - Mullinskaya.]

Наружные поверхности и сколы пластинок барита из туронского писчего мела и девонского биогерма по целому ряд показателей (цвет, характер наслоения, кристаллографический облик, размерность, тонкая структура поверхностей, присутствие эмульсионной взвеси сфалерита в обеих случаях) идентичны, что может свидетельствовать об одновременности их образования в раннеальпийский этап из восходящих металлоносных гидротерм.

Халькопирит установлен в виде кристаллических выделений размером до 2-3 мм. Кристаллы - тетраэдры с преобладающим развитием граней $\{112\}$, в отдельных индивидах выражены грани $\{011\}$. Некоторые кристаллы сдвойникованы. Пирит отмечается в виде пентагондодекаэдров 5-6 мм в поперечнике, встречаются его натечные формы. Для него характерны повышенные количества As $(0.63 \%)$ и $\mathrm{Ni}(0.01 \%)$. Спектральным анализом определены (\%): $\mathrm{Cu}-0.015$, $\mathrm{Pb}-0.0005, \mathrm{Co}-0.004, \mathrm{Zn}-0.08, \mathrm{Mg}-0.5, \mathrm{Mn}-$ $0.012, \mathrm{Ba}-0.063, \mathrm{Al}-5, \mathrm{Ca}-2, \mathrm{Si}-2$.

Наиболее распространенным нерудным минералом является кальцит - одиночные крупные кристаллы, сростки, натечные формы, присыпки, корки, про- жилки. Встречены прозрачные, белые, желтоватые, черные разности (последние в связи с высоким содержанием Mn). Длина кристаллов колеблется от 1-2 мм до 2 см. В таблице 1 даны результаты спектрального анализа кальцитов разных модификаций.

Из таблицы 1 видно, что состав кальцитов разнообразен. Особенно выделяются черные разности, образующие округлые лепешковидные выделения в верхней части пласта метасоматита, где между девонскими и меловыми отложениями имеется маломощный прослой плотной сурки с гальками фосфоритов. В этом кальците больше примесей, чем в прозрачных разностях. Кроме приведенных в таблице, встречены (в \%) $\mathrm{Ag}$ $\left(5 \times 10^{-6}\right), \mathrm{Ga}\left(2 \times 10^{-5}\right)$, Мо $\left(6.3 \times 10^{-5}\right)$, Со $\left(15 \times 10^{-4}\right)$. Содержания марганца, свинца, ванадия, титана на порядок выше, чем в прозрачных кальцитах, но полностью отсутствует стронций, установленный в последних.

Олигонит (марганецсодержащий сидерит) широко распространен. Его ромбоэдры, имеющие нередко изза искажения кристаллографических форм конвертообразный габитус, рассеяны в основной массе породы, на внутренних поверхностях каверн, в полостях кораллитов. Размеры зерен минерала - не более 2 мм,

Табл. 1. Спектральный анализ кальцитов Шкурлатовского проявления

[Table 1. Spectral analysis of calcites of the Shkurlatov manifestation]

\begin{tabular}{|c|c|c|c|c|c|c|c|c|c|c|}
\hline \multirow{2}{*}{$\begin{array}{c}\text { Разновидности кальцита } \\
\text { [Varieties of calcite] }\end{array}$} & \multicolumn{9}{|c|}{ Содержание элементов \% [Content of elements \%] } \\
\cline { 2 - 12 } & $\mathrm{Cu}$ & $\mathrm{Pb}$ & $\mathrm{Ni}$ & $\mathrm{Zn}$ & $\mathrm{V}$ & $\mathrm{Ti}$ & $\mathrm{Mg}$ & $\mathrm{Mn}$ & $\mathrm{Ba}$ & $\mathrm{Sr}$ \\
\cline { 2 - 12 } & $10^{-3}$ & $10^{-4}$ & $10^{-4}$ & $10^{-3}$ & $10^{-4}$ & $10^{-2}$ & $10^{-1}$ & $10^{-3}$ & $10^{-2}$ & $10^{-2}$ \\
\hline Натечный [Deposits] & 0.15 & - & - & 1.5 & 2.5 & 0.8 & 4 & 50 & 25 & 6.3 \\
\hline $\begin{array}{c}\text { Хорошо выраженные скаленоэдры } \\
\text { [Well-defined scalenohedra] }\end{array}$ & 0.4 & 1.5 & - & - & 3.2 & 0.63 & 3.2 & 80 & 3.2 & 5 \\
\hline $\begin{array}{c}\text { Скаленоэдры с закругленными гранями } \\
\text { [The scalenohedron with rounded edges] }\end{array}$ & 0.2 & 1.2 & 6.3 & - & 3.2 & 0.8 & 2.5 & 63 & 2 & 5 \\
\hline Массивный [Massive] & 0.8 & 10 & 25 & 1.5 & 25 & 20 & 10 & 400 & 3.2 & - \\
\hline
\end{tabular}




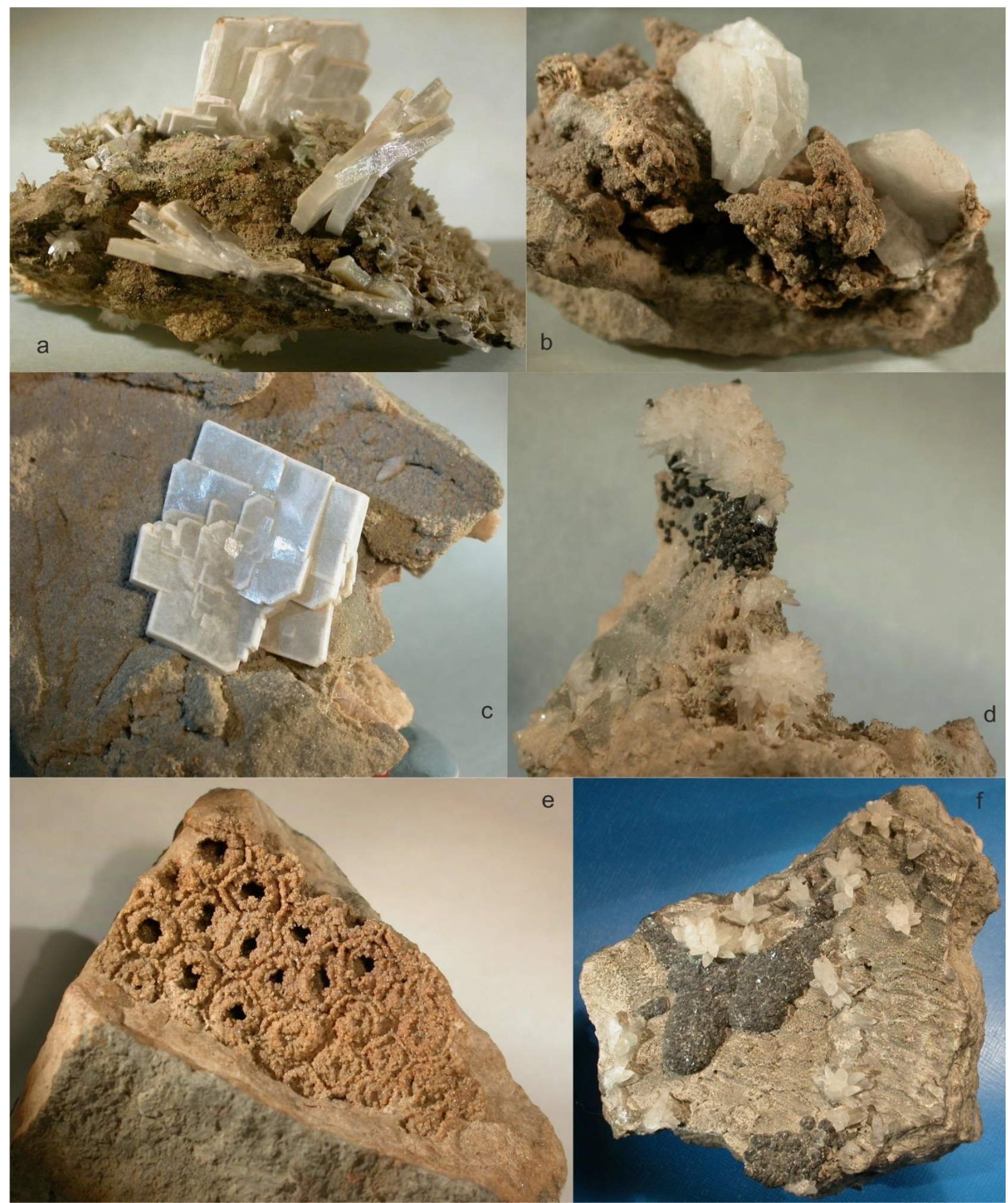

Рис. 13. Минералы из пласта живетского анкеритизированного биогерма Шкурлатовского барит-сфалеритового проявления $\left(\mathrm{D}_{2} \mathrm{ar}\right)$, увеличение $2 \mathrm{x}: a$ - друзы барита на олигонитовой присыпке; $b$ - тонкопластинчатый барит в брекчии гибротермального взрыва; $c$ - голубой барит в пустоте выщелачивания анкерита; $d$ - «шапочка» арагонита на сфалерите; $e$ - кристаллы олигонита на живетских кораллах; $f$ - натечные формы сфалерита в оторочке скаленоэдров арагонита.

[Fig. 13. Minerals from the zhivetsky ankeritized bioherm layer of the Shkurlatovsky barite-sphalerite manifestation $\left(D_{2}\right.$ ar), 2x magnification: $a$-barite druses on oligonite powder; $b$ - thin-plate barite in breccia of the gibrothermal explosion; $c$ - blue barite in the void of the leaching of ankerite; $d$ - "cap" of aragonite on sphalerite; $e$ - oligonite crystals on living corals; $f$-sintering forms of sphalerite in the rim of the aragonite scalenhedrons.] 
сплошных масс - до 15 см и более. Обильная вкрапленность олигонита наблюдалась в кровле пласта анкеритита. Минерал кроме визуального определения подтвержден рентгеноструктурным анализом [1]. Олигонит придает золотистый оттенок породе, облагораживая многие штуфы. Из-за этого пласт анкерита интересен как источник камнецветного сырья.

Позднеальпийская эпоха охватывает палеогеновую трансгрессию и неотектонические масштабные поднятия. В результате рассматриваемая территория превратилась в обширную сушу, где эндогенные процессы тяготели к зонам долгоживущих разломов. К ним приурочены многочисленные эксгаляции ряда металлов, образующих повышенные концентрации в различных по составу и возрасту породах. Поступление летучих по разрывам сопровождалось выносом в осадочный чехол благородных металлов, в результате чего возникли многочисленные проявления ультратонкого золота и интерметаллидов. Они были встречены во многих пунктах в количестве от «единичных знаков» до 3.8 г/м $\mathrm{M}^{3}$ (рис. 3).

Исследования их морфологии, химизма, распределения элементов-примесей, сопутствующих прочих интерметаллидов открыло совершенно необычный мир, отличный от традиционного россыпного золота, следствие иного генезиса ультратонкого металла. Важными оказались не только гранулометрический и минералогический составы вмещающих толщ, но и их структурно-тектоническая позиция, глубинное строение (особенно характер деформаций рельефа поверхностей М и корового раздела), геохимические, петрографические особенности залегающих ниже пород фундамента, присутствие и типы его коренных источников золота, даже неспособных формировать традиционные россыпи. Морфологический облик зерен металла (тонкие неокатанные частицы неправильной формы, рис. 14) и преобладающая размерность (десятки мкм, до 100-150 мкм) идентичны для пород всех подразделений осадочного чехла, меловых, палеогеновых и четвертичных. Они очень мало изменяются по площади.

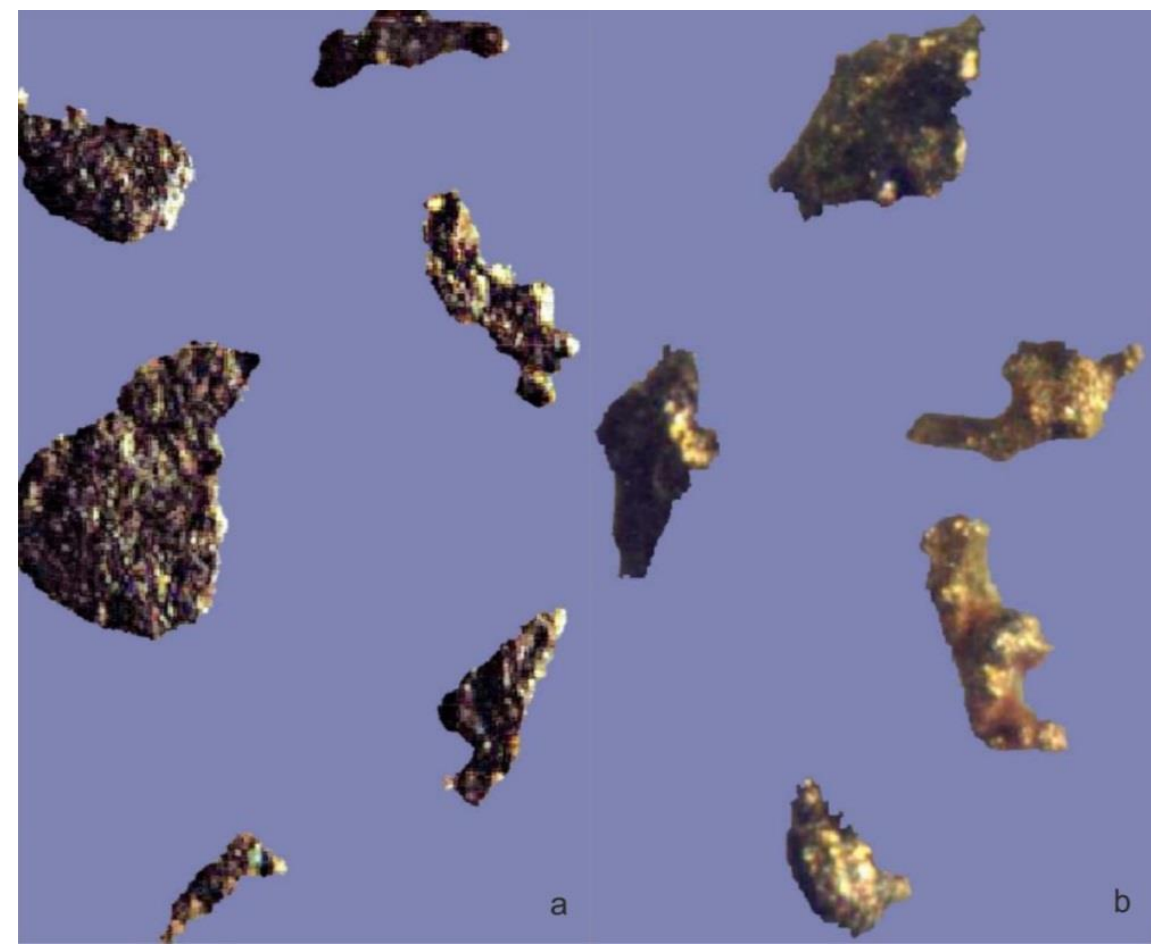

Рис. 14. Золотины: $a$ - из бентонитовых глин киевской свиты эоцена Белгородская области, с. Сергеевка. Размерность зерен 100-250 мкм; $b$ - из базальных песков верхнего палеоцена. Воронежская области, восточная окраина с. Русская Журавка. Размерность зерен 50-60 мкм.

[Fig. 14. Gold: $a$ - from bentonite clays of the kiev formation of the eocene, Belgorod region, v. Sergeevka. The grain size is $100-250$ microns; $b$ - from the basal sands of the upper paleocene. Voronezh region, eastern outskirts of v. Russkaya Zhuravka. The grain size is $50-60$ microns.]
Для определений пробности выполнены химические анализы 60 золотин с использованием рентгеновского микрозонда «Hitachi» (МИТХТ, аналитик А. Д. Сенчуков) для 14 местонахождений золота. В основном пробность менялась в интервале 708-944, но встречены и большие значения, до 956 (палеогеновые охры с. Сергеевка Белгородской области). Близкая к максимальной проба определена ТулаЦНИГРИ и для золота россыпи «Русская Журавка» - 952. В проявлении Нижний Бык (юго-восток Воронежской области, гравийные пески сумской свиты палеоцена) подверглись микрозондированию 5 зерен УТ3; содержания $\mathrm{Au}$ в них соответственно (вес. \%): 27.972,
47.840, 60.110, 70.783, 87.332. Разброс значений между минимальными и максимальными оценками пробности велик - 59.6\%, и лаг (скачок) от зерна к зерну держится на уровне 10-20\%.

Существенный разброс значений характерен и для некоторых других проявлений. В зернах УТЗ из песков $\mathrm{Q}_{\mathrm{II}}$ Кривоборья (север Воронежской области) разрыв в пробности достигает $23.947 \%$, песков $\mathrm{Q}_{\text {III }}$ Тамбовского карьера г. Воронежа $-17.11 \%$. Есть немало местонахождений УТЗ, где диапазон изменений пробности намного меньше. Восемь золотин, отмытых из альбских песков Урыва (Острогожский р-н Воронежской обл.), содержат Аu 77.23-86.63\%, т.е. 
разброс вариаций пробности уложился в 7\%. В Воронежской золотоносной провинции ультратонкие золотины нередко сопровождаются зернами прочих интерметаллидов, природных сложных сплавов, часть которых тоже содержит Au.

Материалы по примесям в классическом россыпном золоте систематизировал Н. А. Шило [16]. По его данным, соотношение $\mathrm{Au}$ и $\mathrm{Ag}$ в россыпных месторождениях полностью наследуется от коренных источников. Этот автор разделил примеси на три группы. К первой отнесены элементы, образующие с золотом 16 основных минералов. Это электрум Au и Ag, амальгама золота $\mathrm{Au}, \mathrm{Hg}$ (содержания $\mathrm{Hg}$ до 60-70\%), купроаурит $\mathrm{Au}, \mathrm{Cu}$, мальдонит $\mathrm{Au}_{2} \mathrm{Bi}$, висмутоаурит $\mathrm{Au}, \mathrm{Bi}$, платиноаурит $\mathrm{Au}, \mathrm{Pt}$, порпецит $\mathrm{Au}, \mathrm{Pd}$, иридийаурит $\mathrm{Au}, \mathrm{Ir}$, родийаурит $\mathrm{Rh}, \mathrm{Au}$, сильванит $\mathrm{AuAgTe,} \mathrm{мутманиит}$ $(\mathrm{Ag}, \mathrm{Au}) \mathrm{Te}$, петцит $(\mathrm{Ag}, \mathrm{Au}) \mathrm{Te}_{2}$, калаверит $(\mathrm{Au}, \mathrm{Ag}) \mathrm{Te}_{2}$, монтбрейит $\mathrm{Au}_{2} \mathrm{Te}_{3}$, криннерит (Au,Ag)Te $\mathrm{T}_{2}$, нагиагит $\mathrm{Pb}_{5} \mathrm{AuSbTeS}_{6}$. Медь участвует в составе купроаурита; ее содержания в золоте возрастают в меденосных регионах, платины - в платиноносных. Н. А. Шило связывал с присутствием Pt в золотинах соответствующие перспективы прилегающих территорий. Отмечена особая роль среди примесей в россыпном золоте теллура: 7 из 16 минералов золота теллуриды.

Во вторую группу включены 30 элементов, среди которых есть встречающиеся: 1 - часто (Pb, Zn, Sb, As). Почти в каждой пробе обнаруживаются также Fe, $\mathrm{Si}, \mathrm{Al}$, обычны $\mathrm{Na}, \mathrm{K}$. Присутствие последних пяти элементов связывают с механическими примесями. Прочие элементы, возможно, входят в состав минералов, ассоциирующих с золотом; 2 - редко (Mn, Mo); 3 - очень редко ( $\mathrm{Sn}, \mathrm{Co}, \mathrm{Ba}, \mathrm{Sr})$. К третьей группе отнесены редко обнаруживаемые $\mathrm{Cr}, \mathrm{V}, \mathrm{Hf}$, присутствие которых Н. А. Шило объяснил засорением проб либо вхождением их в минералы, находящихся в парагенезисе с золотом.

Несомненно, состав и количество примесей в золоте предопределены генезисом, возрастом, геохимической ситуацией каждого проявления, россыпного или коренного. Золотины экзогенных месторождений содержат более бедный спектр химических элементов. Этот эффект самоочищения сформулирован в свое время А.Е. Ферсманом. Но эту мысль нельзя абсолютизировать. Так почти чистое эксгаляционное УТЗ Толбачика, отлагавшееся во время Большого трещинного извержения 1975-1976 гг. [17].

Ультратонкие золотины проявлений Воронежской провинции содержат практически все элементы, упомянутые в работе Н. А. Шило, а также целый ряд в ней отсутствующих: прочие металлы платиновой группы, $\mathrm{Zr}, \mathrm{Tl}, \mathrm{Se}, \mathrm{In}$. При этом примеси занимают от 4.734 до 71.987 вес. \%. Некоторые специалисты в области металлогении подобное золото называют «грязным» и считают особенностью докембрийского рудогенеза. Между тем золотины Воронежской провинции - явные новообразования. Самые общие геохимические особенности воронежского ультратонкого золота по данным рентгеновского микрозондирования следующие:
1 - очень низкое содержание серебра, до полного его отсутствия даже в тысячных долях процента, зерна 31-33, 46, отмытые из палеогеновых проявлений Сергеевки и Нижнего Быка, что не свойственно россыпям Сибири и Мира в целом;

2 - уже отмеченное высокое содержание летучих элементов - Hg, Sb, Ta, Te, As, Sb. В зерне из проявления Нижний Бык (порядковый № 60) наряду с теллуром $(0.459 \%)$ встречен и селен $-0.354 \%$. Из 60 зерен ртути не оказалось лишь в 16 зернах (27\% случаев). Остальные золотины причислены к так называемым «твердым амальгамам», в которых $\mathrm{Hg}$ от десятых долей до $13.098 \%$. При этом ртуть распределена равномерно по всему срезу золотины. Распределение этого металла по площади зерен изучено в Институте тонких химических технологий (аналитик А. Д. Сенчуков). Другой летучий элемент золотин - Та, реагирующий с кислородом уже при комнатной температуре, присутствует в 11 случаях (17\% зерен). Его от долей до $18.914 \%$, обычно же от нуля до первых процентов. As обнаружен в 48 зернах (77\%) в значениях от $0.025 \%$ до $1.764 \%$. Sb (24 случая, $38 \%$ ), столько же, как и As - 0.01-1.335\%;

3 - постоянное, кроме 3 случаев из 60, присутствие металлов платиновой группы МПГ. В количествах до 1\% они установлены в 12 зернах (20\%), 1-5\% - в $23(40 \%), 5-10 \%$ - в $15(25 \%), 10-15 \%$ - в $5(8.2 \%)$, более $15 \%$ - в 2 (3\%);

4 - присутствие в значительных, хотя и не определяющих количествах, прочих примесей, среди которых цинк и сродственные $\mathrm{Cd}$ и $\mathrm{In} ; \mathrm{Cu}, \mathrm{Sn}, \mathrm{Pb}, \mathrm{Bi}$; элементы группы железа; цирконий и родственный ему гафний; алюминий, кремний.

Помимо эксгаляционных процессов имеются признаки алмазоносного магматизма по наличию в базальных горизонтах мелких зерен алмазов и их минералов-спутников. Они известны в циркон-титановой россыпи у г. Новозыбков на северо-западе антеклизы и в основании разреза палеогена (сумская свита $\mathrm{P}_{1} \mathrm{~s}$ ) ее юго-востока. Обнаружены также несколько пунктов с находками индикаторных минералов в дочетвертичных толщах (ледниковые и постледниковые образования контаминированы северным алмазоносным материалом и неинформативны).

В 1971 г. при опробовании Новызыбковской россыпи титан-циркониевых песков (запад Брянской области), связанной с полтавскими отложениями $\mathrm{P}_{3}$ $\mathrm{N}_{1} \mathrm{pl}$, Ю. А. Полкановым было встречено 21 зерно алмаза размерностью 0.1-0.25 мм. Отдельные залежи россыпи (Александрия) содержат до 350 кг/т тяжелых минералов в интервалах разреза мощностью до 2.5 м.

Работами авторов из отложений сумской свиты (проба 7001, разрез Нижний Бык) выделено 15 пиропов фиолетовой до розовой окраски (рис. 15) и диаметром 0.2-0.6 мм. Они слабо окатаны, представлены угловатыми обломками неправильной формы, реже встречаются осколки с острыми краями. Поверхность зерен механогенная и гипергенно-механогенная, последняя проявлена в виде конусовидных бугорков. 


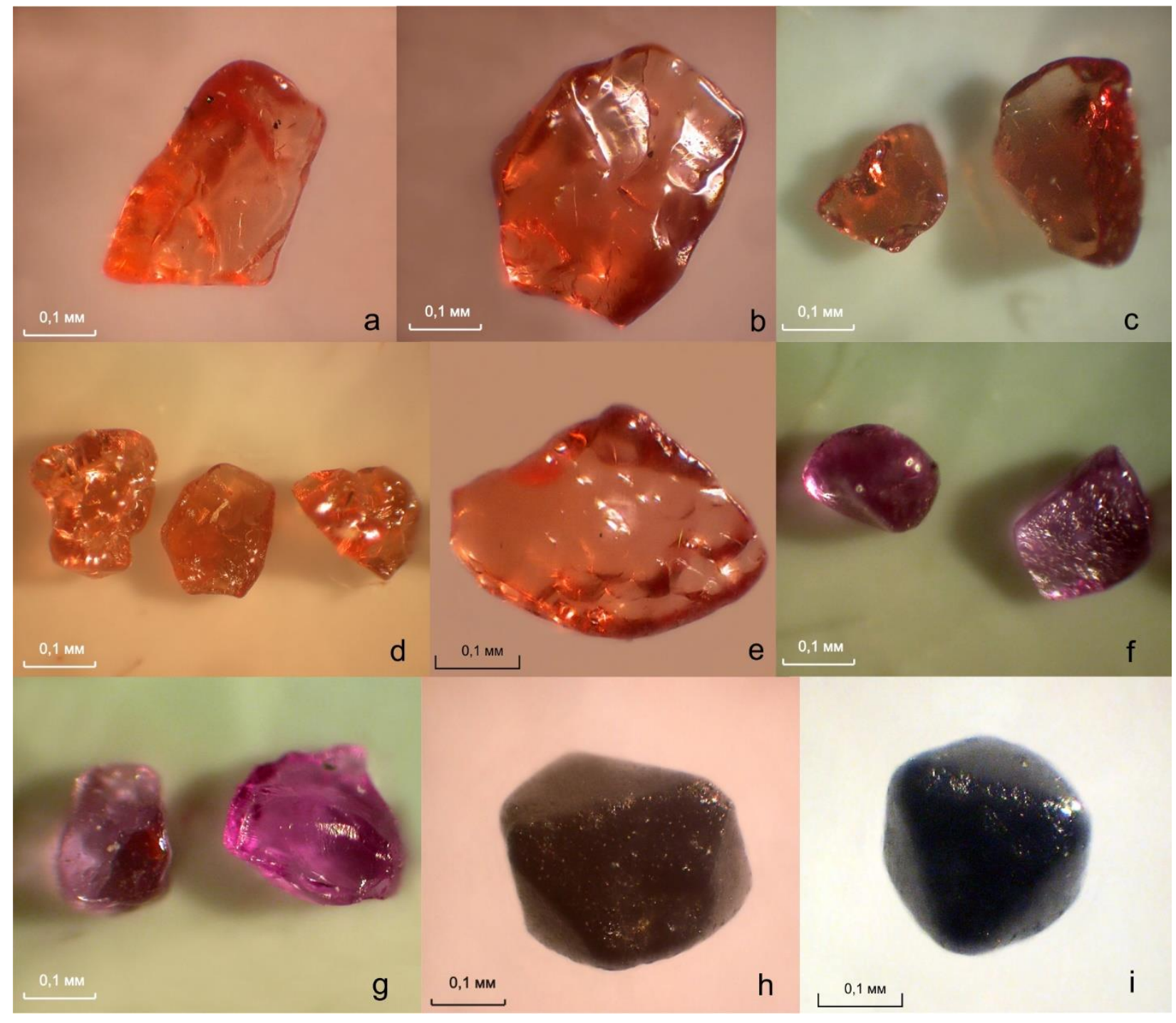

Рис. 15. Минералы-индикаторы кимберлитов из отложений палеогена: $a$-c - пиропы, проба $7001 ; d-e$ - зерна пиропов из пробы 7002; f-g - фиолетовые пиропы, проба 7003; $h-i-$ хромшпинелиды из пробы 7003.

[Fig. 15. Mineral indicators of kimberlites from paleogene deposits: $a-c$ - pyrope, sample $7001 ; d-e$ - pyrope grains from sample 7002; $f-g$ - purple pyrope, sample 7003; $h-i$ - chrome spinels from sample 7003.]

Содержание $\mathrm{Cr}_{2} \mathrm{O}_{3}$ от 0.1 мас. \% - в пироп-альмандинах до $9.34 \%$ - в пиропах.

Очень богаты пиропами прибрежно-морские базальные пески бучакского горизонта в разрезе Жилино-Поддубный, южная часть Россошанского срединного массива [18]. Из пробы 7003 массой 2.3 т извлечено 79 только фиолетовых разностей, четверть в гранулометрическом классе 0.5-0.9 мм, т.е. размерностью до крупных песков. Превалирует 2-ой класс окатанности, отдельных зерен - до 4-го класса. Преобладающий тип поверхности механогенный, гипергенномеханогенный развит в меньшей степени. Окраска пиропов зависит от их химического состава. Чем больше хрома в гранате, тем его фиолетовая окраска гуще. Рентгеноспектральным анализом подтверждено кимберлитовое происхождение отдельных зерен минерала $\left(\mathrm{Cr}_{2} \mathrm{O}_{3}\right.$ до 9.34\%).

$\mathrm{B}$ разрезах палеогена Донского левобережья у с. Жилино и х. Поддубного отмечены наиболее высо- кие содержания пиропов, из которых отдельные по геохимическим показателям принадлежат алмазоносной дунит-гарцбургитовой ассоциации. Это наиболее крупные пиропы из обнаруженных в дочетвертичных отложениях Воронежской антеклизы.

Хромшпинелиды (рис. 15) обнаружены в пробах из отложений сумской и бучакской свит, их содержания колеблются от 4 до 10 зерен. Они представлены октаэдрическими кристаллами размером 0.1-0.2, реже до 0.5 мм. Хромшпинелиды 2-ой и 3-ей степеней окатанности, октаэдры искажены по одной из осей. Вершины и ребра минералов сглажены, реже встречаются острореберные кристаллы. Преобладающий тип поверхности механогенный. Они низкохромистые, $\mathrm{Cr}_{2} \mathrm{O}_{3}$ в них (мас. \%) от 24.5 до 41.1, $\mathrm{TiO}_{2}$ от 0.27 до 6.5, $\mathrm{MgO}$ до 17.2.

Пикроильмениты выделены в виде единичных зерен из отложений сумской и бучакской свит. Зерна тяготеют к крупным размерным классам (более 0.25 
мм), они, как правило, хорошо окатаны (3-4 класс). Минералы низко магнезиальные, $\mathrm{MgO}$ в них от 0.96 до 5.86 мас. \%.

Алмазы установлены в трех разрезах, всего обнаружено 7 мелких кристаллов [19]. На участках Мамоновка и Нижний Бык обнаружены по 3 алмаза, участке Ержовка-1. Представлены октаэдрами и обломками кристаллов серого и светло-серого цветов.

На северо-востоке из неогеновых отложений выделен комплекс МСА - хромшпинелиды и пиропы [18]. Зерна хромшпинелидов размером от 0.1 до 0.25 мм (рис. 16) представлены плоскогранными октаэдрами, а содержания в пробах - от 7 до 43 знаков. Зерна, как правило, хорошо окатаны (3 класс), встречаются и интенсивно окатанные 4-го класса.

Пиропы отмечаются в 4 разрезах, их от 1 до 3 зерен в одной пробе. Они фиолетовой, реже розовофиолетовой окраски различной интенсивности, угловато-окатанные, размером обычно 0.16-0.25 мм.
Встречаются также пиропы, имеющие форму куба. Отмечается два типа поверхности - гипергенного растворения и механогенная, с преобладанием первой. Зерна хорошо окатаны (3 класс). Гипергенное растворение выражено в развитии на поверхности зерен бугорчатости, каплевидности и тригональных фигур травления. Механический износ пиропов выражен в появлении микрорельефа - микровыбоин и сглаженной «леденцовой» поверхности. По зернам видно, что они сначала подверглись гипергенному растворению, а затем были окатаны. $\mathrm{Cr}_{2} \mathrm{O}_{3}$ в изученных гранатах от 1.2 до 5.15 мас. \%, количество $\mathrm{CaO}$ колеблется незначительно, от 4.04 до 5.91, $\mathrm{MgO}-$ $18.2-23.58 \%$. По соотношению $\mathrm{Cr}_{2} \mathrm{O}_{3}$ и $\mathrm{CaO}$ на диаграмме Н. В. Соболева практически все пробы попадают в область гранатов лерцолитового парагенезиса, и только одна - в область дунит-гарцбургитового парагенезиса.

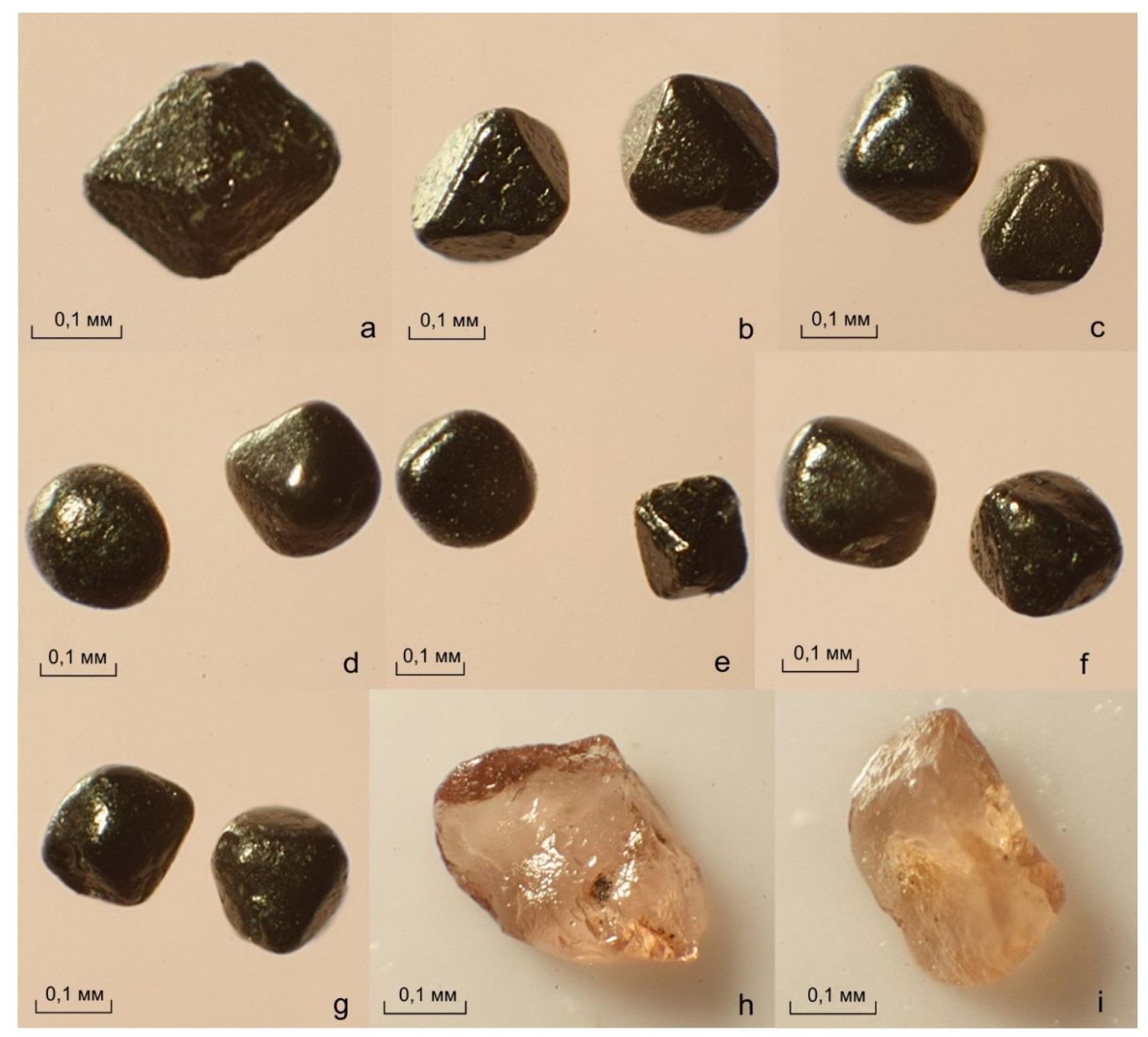

Рис. 16. Морфологические особенности МСА (т.н. 12): $a-g$ - хромшпинелиды; $h-i-$ гранаты.

[Fig. 16. Morphological features of the DSM (watchpoint 12): $a-g$ - chrome spinelids; $h-i$ - garnet.] 


\section{Обсуждение результатов}

Анализ полученных за последние полтора десятилетия новых данных по эндогенным проявлениям и их минерагеническим особенностям позволил выделить следующие эпохи тектонической активизации рассматриваемого региона: 1 - раннегерцинскую $\left(\mathrm{D}_{2}-\mathrm{C}_{1}\right)$, 2 - позднегерцинскую $\left(\mathrm{C}_{2}-\mathrm{T}_{1}\right), 3$ - раннекиммерийскую $\left(\mathrm{T}_{2}-\mathrm{J}_{1}\right), 4$ - позднекиммерийскую $\left(\mathrm{J}_{2}-\mathrm{K}_{1}\right), 5-$ раннеальпийскую $\left(\mathrm{K}_{2}-\mathrm{P}_{3}\right), 6$ - позднеальпийскую $(\mathrm{N}$ Q). Каждая из них обычно проявлена в определенных районах антеклизы и содержит свой набор пород и руд. Он зависит от коромантийного источника рудного вещества, а также состава осадочных пород, в которых оно концентрируется на геохимических и литологических барьерах.

Раннегеричинская эпоха. При разнонаправленных движениях блоков фундамента проявляется наибольшая амплитуда тектонических движений. Она преимущественно проявляется в краевых частях антеклизы, тяготеющих к авлакогенам и прогибам. При этом осуществляется связь с мантийными источниками, что сопровождается базальтовым магматизмом. Такие явления характерны для раннегерцинского этапа. Наиболее ранние эйфельские вулканиты зафиксированы в Калужской структуре на севере антеклизы на границе со Среднерусским авлакогеном, в зоне Труфановско-Павелецких поднятий.

На границе живета и франа в пределах юговостока ВА проявился эксплозивный магматизм с образованием вулканогенно-осадочных пород и связанных с ними титановых россыпей. Позднее, в петинское время на юго-востоке, а в евлано-ливенское на востоке антеклизы в зоне развития МигулинскоНовохоперской тектонической зоне глубинных разломов произошло излияние базальтов линейнотрещинного типа. При этом образовались три поля развития этих пород мощностью от первых до нескольких десятков метров. Предположительно в это же время на юго-востоке внедрились протрузии гипербазитов [1], несущие медно-никелевое оруденение. Связанные с ними эксгаляции обусловили образование прослоев медно-никелевого оруденения в песчано-каолиновой толще. Оно тяготеет к пескам, перекрытым слоем глин, представляющих литологический барьер.

В пределах центральной части антеклизы с ее мощной корой континентального слоя источником рудного вещества служили породы кислого состава. Здесь отмечается свинцово-цинковая минерализация в алевропесчаных породах, тяготеющих к полям трещиноватости в зонах глубинных разломов.

С раннегерцинской эпохой тектогенеза связаны месторождения алмазов Вилюйской (Якутия) и КольскоАрхангельской провинций. Многие специалисты, в т. ч. С. И. Митюхин [20], М. В. Михайлов [21], убеждены: на Воронежской антеклизе если и есть кимберлиты, то только среднепалеозойской продуктивной эпохи. Проведенное нами и другими исследователями изучение большого количества проб базальных гори- зонтов девона и нижнего карбона пока не выявило в них ни алмазов, ни их минералов-спутников. Только в базальном горизонте визе Курского грабена установлены единичные зерна хромшпинелидов, в т.ч. алмазной ассоциации. В песчаных породах этого горизонта обнаружены сульфиды свинца и цинка, что дает возможность предполагать эндогенные процессы в эту эпоху. Вместе с тем не исключено, что эти проявления связаны с более поздними эпохами.

Позднегеричиская эпоха наиболее слабо обоснована из-за почти полного отсутствия верхнепалеозойских отложений. Тем не менее по возрасту 260$290 \pm 12$ млн лет кварц-полевошпатовой дайки в мамонской толще можно предполагать энодогенное происхождение ореолов рассеяния меди и никеля, поступавших при активизации глубинных разломов в полях развития гипербазитов. Такой ореол хорошо изучен над интрузией «Липов куст», но повышенные содержания этих элементов отмечаются в осадочных породах и над телами других гипербазитов. Наличие такого ореола может служить поисковым признаком при поисках новых медно-никелевых месторождений в зоне Хоперского мегаблока (рис. 1). На его территории расположена новая никеленосная провинция, связанная с базит-гипербазитовым магматизмом.

Раннекиммерийская эпоха характеризуется перестройкой тектонической структуры региона, резким поднятием ее территории, образованием Доно-Донецкого моста в ее центральной части и размывом осадочных отложений, в отдельных участках вплоть до кристаллического фундамента. Восходящие тектонические движения по глубинным разломам активизировали проникновение рудоносных растворов в породы осадочного чехла с образованием проявлений полиметаллов, флюорита, барита, особенно в участках, граничащих с Донбассом. В этом плане рассматриваемая эпоха оказалась наиболее продуктивной в фанерозое.

Рудные тела полиметаллов тяготеют к зонам тектонических нарушений высоких порядков и расположены в пределах Белгородско-Марковской зоны. Цепочки рудопроявлений прослежены до границы Белгородской области в соседних районах Украины. Следовательно, перспективы обнаружения рудных тел на юго-западе антеклизы не ниже, чем на Украине, так как в структурном отношении эти площади едины, мощности же осадочного чехла на КМА меньше.

В раннекимерийскую эпоху впервые в базальных горизонтах юры появляются первые алмазы и их минералы-спутники. Это первые достоверные свидетельства проявлений кимберлитового магматизма, установленные на антеклизе.

$B$ позднекиммерийскую эпоху после средне- и позднеюрских трансгрессий из Днепровско-Донецкой впадины на юго-западном склоне и со стороны Волги на северо-востоке антеклизы начались постепенные поднятия территории. В неокоме морские воды вступали в регион с севера и северо-запада. При этом размывались юрские и девонские породы и 
формировались полифациальные терригенные осадки. В них отмечаются мелкие зерна алмазов и их минералы-спутники, во многом похожие на юрские. Плохая обнаженность неокомских отложений, их изолированность, тонкий равномерный гранулометрический состав снижают интерес к их опробованию на алмазы. Исключением являются периферические части Воронежской антеклизы, где выявлены образовавшиеся в подводных условиях барремского века на тектонических поднятиях титан-циркониевые россыпи дальнего переноса, например - Скопинская площадь Рязанской области

$\mathrm{B}$ аптский век поднятия региона, достигли своего максимума, когда он почти полностью был осушен. На большей части территории ВА существовала внутриконтинентальная аллювиальная равнина, переходившая к северу в равнину прибрежно-морскую, далее сменяемую мелким шельфом.

Континентальные (аллювиальные, озерные) аптские толщи, развитые в центральной части ВА, мало информативны для общерегиональной характеристики алмазоносности из-за ограниченности своих частных площадей сноса. Для этих целей годятся только прибрежно- и мелководно-морские образования с естественными скоплениями тяжелых минералов. В регионе они имеют ограниченное распространение и наблюдаются только в северной части ВА.

В такой связи большой интерес представляют морские отложения среднего альба, накопление которых ознаменовало начало очередного (альб - маастрихтского, или позднемелового) этапа. Молодое трансгрессирующее море легко высвобождало из осадочных пород минералы тяжелой фракции, накапливая их в базальном горизонте. Поэтому в разрезах альба карьеров КМА, Верхне-Турово даже в небольших по объему пробах $-0.2 \mathrm{~m}^{3},-$ обнаруживаются многочисленные пиропы. Сеноманские пески и фосфоритовые галечники без видимого перерыва продолжили альбское осадконакопление. Лишь в пределах архейского Россошанского срединного массива, имевшего тенденцию к высокому положению в мелу, известны разрезы, где сеноманские псаммиты залегают на девонских и каменноугольных породах.

Наличие мелких алмазов и их минералов-спутников в позднеюрских и особенно в нижнемеловых отложениях свидетельствуют о кимберлитовом (лампроитовом) магматизме в позднекиммерийскую эпоху. Он проявился в пограничных частях срединных архейских массивов с Лосевской (Ливенско-Богучарской) шовной зоной сочленения Сарматии и ВолгоУралии.

Раннеальпийская эпоха характеризуется обширными опусканиями в позднемеловое время, когда море покрыло всю территорию антеклизы, и сформировалась мощная мергельно-меловая толща. В палеоцене оно регрессировало и в результате поднятия территории на карбонатном субстрате образовалась своеобразная охристо-глинистая кора выветривания хоперский горизонт $[22,23]$, фиксирующий поверх- ность выравнивания. Поднятие сопровождалось тектонической активизацией зон разломов, внедрением протрузий гранитодных пород. В такие зоны, как показано выше, могли поступать гидротермальные растворы и отлагаться рудные минералы. Все описанные проявления тяготеют к Лосевской шовной зоне, активной в течение всего фанерозоя

Но помимо рудоносности проявился и алмазоносный магматизм, о чем свидетельствует наличие мелких алмазов и их минералов-спутников в песках палеоцена и эоцена. При этом следует иметь в виду, что карбонатные, а также кремнеземистые, терригенные отложения верхнего мела накапливались на всей территории антеклизы. Это важно для алмазопоисковых целей, значения для интерпретации данных опробования, выделения продуктивных эпох, в частности, весьма вероятной, позднемеловой-раннепалеогеновой (датско-раннепалеоценовой). И особенно это актуально для юго-востока Воронежской антеклизы, ее обширного Россошанского прогнозируемого кимберлитового района [24-26]. Там велика экранирующая роль писчего мела. Сплошное развитие этой породы делало невозможным поступление акцессорных минералов из древних коллекторов и гипотетических трубок взрыва в поздние осадочные бассейны. Становится понятнее резкое несходство минеральных ассоциаций дотуронских и послемеловых пород. Присутствие алмаза и его генетических спутников в песках палеоцена и эоцена могло происходить из диатрем датско-раннепалеоценовой эпохи.

Позднеальпийская эпоха проявления эндогенных процессов связана с поднятием рассматриваемой территории, регрессии с нее морей и превращение ее в сушу. При этом значительное развитие получили эксгаляционные процессы, связанные с зонами глубинных мантийных и коровых разломов. Это привело к появлению ультратонкого золота и интерметаллидов, содержащих летучие компоненты [27]. Подобные процессы широко проявились в Волго-Камской впадине [28].

Особенности локализации и формы нахождения свободного золота в осадочном чехле (ультратонкие размеры золотин, насыщенность их летучими компонентами, тяготение проявлений к зонам разрывов) позволили предположить возможность открытия новой Воронежской золотоносной провинции. Ее площадь едина в структурном отношении, так как совпадает с Воронежской антеклизой. С учетом блоковости строения кристаллического фундамента в ее пределах возможны несколько металлогенических зон (районов) I порядка, в свою очередь делящихся на зоны (подрайоны) II порядка.

\section{Заключение}

При становлении и перестройках палеозойской тектонической структуры Воронежской антеклизы неоднократно проявлялись эндогенные процессы. Они выражались в вулканической деятельности, воздействии на осадочные породы гидротерм и эксгаля- 
ций, возможном кимберлитовом магматизме. Выделяется шесть эпох проявления таких процессов, каждая из них имеет свои специфические особенности.

В раннегерцинскую эпоху магматизм проявился в несколько этапов. Наиболее ранний из них щелочнобазальтовый в Калужско-Бельской структуре на севеpe BA датирован эйфельским веком, Эксплозивный ястребовский на юго-востоке региона по возрасту отвечает границе живета и франа. В начале позднефранского (петинского) времени, в меньшей степени в его конце (евлано-ливенского), произошли излияния толеитовых базальтов (потоковые и жерловые), образовавших несколько полей. Аналоги подобных излияний на Восточно-Европейской платформе имеются в Днепровско-Донецкой впадине и на Тимане. Вулканизм связан с мантийными источниками, как и протерозойские гипербазиты, несущие сульфидное медноникелевое оруденение. Над ними отмечаются позднегерцинские ореолы рассеяния никеля, кобальта и меди в осадочном чехле, поступавшие из эксгаляций по зонам трещиноватости на контактах интрузий с вмещающими породами.

С раннекиммерийской эпохой связано гидротермальное полиметаллическое оруденение в терригенно-карбонатных образованиях каменноугольной системы в пограничных областях ВА и Днепровско-Донецкой впадины. Оно приурочено к глубинным зонам коровых разломов в пределах Белгородско-Марковской зоны, по которым свинец и цинк гидротермами поставлялись в осадочный чехол.

Позднекиммерийская эпоха характеризуется появлением в базальных горизонтах верхнеюрских и нижнемеловых отложений значительных содержаний мелких алмазов и их минералов-спутников. Это свидетельствует о кимберлитовом (лампроитовом) магматизме в пределах срединных архейских массивов с повышенной мощностью континентальной коры. Новая вспышка такого магматизма отмечается в раннеальпийскую эпоху, когда породы юры и нижнего мела были полностью перекрыты, а состав и соотношение высокобарических минералов тяжелой фракции значительно изменились. Кимберлитовые диатремы могли появиться в мел-палеогеновый перерыв при поднятии региона.

В эту же эпоху проявились гидротермальные процессы в районе Шкурлатского гранитного карьера при формировании граносиенитовой протрузии. Флюиды, поступавшие при ее движении вверх сформировали по кораллиту анкеритовый метасоматит, обогащенный баритом, олигонитом, сфалеритом и другими гидротермальными минералами.

Позднеальпийская эпоха отличается поднятием региона с разгрузкой напряжений. Она вызвала повышенную трещиноватость пород, особенно в Ливенско-Богучарской шовной зоне сочленения Сарматии и Волго-Уралии. Это сопровождалось эксгаляционными процессами с образованием в осадочном чехле ультратонкого золота и интерметаллидов, обогащенных летучими металлами.

Эндогенные процессы, наложенные на породы осадочного чехла, привели к формированию ряда полезных ископаемых различного генезиса, поиски и разведка которых могут привести к открытию новых для региона месторождений. С девонским магматизмом связаны вулканогенно-осадочные россыпи титана, в которых содержание ильменита достигает первых сотен кг/ $\mathrm{M}^{3}$, базальтов для производства балластного щебня и каменного литья. Базальты и россыпи ильменита на юго-востоке антеклизы присутствуют во вскрыше медно-никелевых, графитовых месторождений и над куполами гранитоидов, что открывает возможности для их комплексной отработки. Ценность месторождений увеличивают осадочные полезные ископаемые, залегающие во вскрыше - каолины, кварцевые пески, мела, кирпичные суглинки.

Гидротермальные процессы мезозое привели к появлению руд сульфидов полиметаллов в породах карбона на юго-западе антеклизы, где прослеживается цепочка их проявлений в зонах развития глубинных разломов. В кайнозое с эскалациями в осадочный чехол связаны проявления ультратонкого золота, одно из которых Русская Журавка на юго-востоке было разведано в прошлом столетии. Однако из-за трудностей извлечения металла (7-12\%) геологоразведочные работы не были продолжены. С появлением новых технологий они могут быть возобновлены.

Наличие мелких алмазов и их минералов-спутников в базальных горизонтах осадочного чехла позволяют предположить алмазоносный кимберлитовый магматизм в фанерозойской истории антеклизы. Проведенные исследования позволяют прогнозировать три эпохи его проявления - позднегерцинскую, позднекиммерийскую и раннеальпийскую. Наиболее достоверной из них является вторая. Поэтому кимберлиты в первую очередь следует искать под нижнемеловыми образованиями.

Конфликт интересов: Авторы декларируют отсутствие явных и потенциальных конфликтов интересов, связанных с публикацией настоящей статьи.

\section{ЛИТЕРАТУРА}

1. Шевырев Л. Т., Савко А. Д., Шишов А. В. Эволюция тектонической структуры Воронежской антеклизы и ее эндогенный рудогенез. Труды научно-исследовательского института геологии. Воронеж: Изд-во Воронеж. гос. ун-та. Вып. 25, 2004. 112 c. https://www.elibrary.ru/item.asp?id=21768044 (дата обращения: 12.02.2020).

2. Шевырев Л. Т., Савко А. Д. Полезные ископаемые зон тектонической активизации южной части Воронежской антеклизы. Труды научно-исследовательского института геологии. Воронеж: Изд-во Воронеж. гос. ун-та. Вып. 62, 2011. 106 c. https://www.elibrary.ru/item.asp?id=21768043 (дата обращения: 12.02.2020).

3. Савко А. Д., Хожаинов Н. П. Этапы формирования кор выветривания в позднем протерозое и палеозое Воронежской антеклизы // Литогенез в докембрии и фанерозое Воронежской антеклизы. Воронеж: Изд-во Воронеж. гос. ун- 
та, 1975. С. 49-59. https://www.elibrary.ru/item.asp?id= 23081099 (дата обращения: 12.02.2020).

4. Милаш А. В., Савко А. Д. Литология девонских отложений юго-востока Воронежской антеклизы. Труды научноисследовательского института геологии. Воронеж: Изд-во Воронеж. гос. ун-та. Вып. 100, 2017. 122 c. https://www.elibrary.ru/item.asp?id=30314171 (дата обращения: 12.02.2020).

5. Быков И. Н. Верхнедевонские базальты на юговосточной части Воронежской антеклизы. Воронеж: Изд-во Воронеж. гос. ун-та, 1975. 134 с.

6. Юткина Е. В., Носова А. А., Сазонова Л. В., Ларионова Ю. О., Кондрашова И. А., Шумлянский Л. В., Альбеков А. Ю., Савко К. А. Девонские вулканиты Воронежского кристаллического массива Восточно-Европейской платформы: эволюция расплавов и особенности коровой контаминации // Петрология. 2017. Т. 25. № 3. С. 233-264. https://www.elibrary.ru/item.asp?id=29404792 (дата обращения: 12.02.2020).

7. Савко А. Д., Мануковский С. В., Шевырев Л. Т. Литология и полезные ископаемые мамонской песчано-каолиновой толщи Воронежской антеклизы. Труды научно-исследовательского института геологии. Воронеж: Изд-во Воронеж. гос. ун-та. Вып. 53, 2008. 112 c. https://www.elibrary.ru/item.asp?id=21768060 (дата обращения: 12.02.2020).

8. Агейкин А. С., Чернышов Н. М., Молотков С. П., Буковшин В. В. Медная и никелевая минерализация в терригенных отложениях верхнего девона на юго-востоке Воронежской антеклизы // Сов. Геология. 1968. № 1. С. 122-125. https://www.elibrary.ru/item.asp?id=35548166 (дата обращения: 12.02.2020).

9. Зеленщиков Г. В., Давыденко Д. В. Анализ блоковой тектоники юго-восточного склона Воронежского кристаллического массива // Геотектоника. 1978. № 3. С. 38-48.

10. Черешинский А. В. Минералы-индикаторы кимберлитов палеозойского промежуточного коллектора Воронежской антеклизы // Вестник Воронежского государственного университета. Серия: Геология. 2016. № 1. С. 76-82. https://www.elibrary.ru/item.asp?id=25942774 (дата обращения: 12.02.2020).

11. Савко А. Д., Шевырев Л. Т. Минерагения осадочного чехла Воронежской антеклизы. Труды научноисследовательского института геологии. Воронеж: Изд-во Воронеж. гос. ун-та. Вып. 49, 2007. 99 c. https://www.elibrary.ru/item.asp?id=21763974 (дата обращения: 12.02.2020).

12. Шумлянский В. А. Киммерийская металлогеническая эпоха на территории Украины. Киев: Наукова думка, 1983. $220 \mathrm{c}$.

13. Сущук Е. Г. Старобельско-Миллеровский металлогенический район // Металлогения фанерозоя платформенной части Украины. Киев: Наукова думка, 1984. С. 136-139.

14. Багно Г. Ф., Машир В. Н. О новых проявлениях Pb-Zn оруденения в каменноугольных отложениях на южном склоне Воронежской антеклизы // Геологический журнал. 1969. № 1. С.105-106.

15. Черешинский А. В. Минералы-индикаторы кимберлитов мезозойского промежуточного коллектора Воронежской антеклизы // Вестник Воронежского государственного университета. Серия: Геология. 2017. № 2. С. 107-114. https://www.elibrary.ru/item.asp?id=29407072 (дата обращения: 12.02.2020).

16. Шило Н. А. Учение о россыпях. Владивосток: Даль наука, 2002. 576 c. http://www.geokniga.org/books/8614 (дата обращения: 12.02.2020).

17. Вергасова Л. П. Набоко С. И., Серафимова В. Л., Старова В. Л., Филатов С. К. Эксгаляционное самородное золото // ДАН. 1982. Т. 264. № 1. С. 201-204.

18. Черешинский А. В. Минералы-индикаторы кимберлитов кайнозойского промежуточного коллектора Воронежской антеклизы // Вестник Воронежского государственного университета. Серия: Геология. 2017. № 3. С. 75-81. https://www.elibrary.ru/item.asp?id=30005142 (дата обращения: 12.02.2020)

19. Черешинский А. В. Мелкие алмазы Воронежской антеклизы: распространение, особенности, происхождение // Вестник Воронежского государственного университета. Серия: Геология. 2015. № 3. С. 83-89. https://www.elibrary.ru/item.asp?id=25942718 (дата обращения: 12.02.2020).

20. Митюхин С. И. Геолого-генетические и эмпирические основы выделения таксона класса субпровинции кимберлитов и конвергентных им пород // Отечественная геология. 1997. № 1. С. $23-28$.

21. Михайлов М. В., Беляев Г. А., Кузьмина Т. С., Ладыгина М. Ю., Поляков А. А. Перспективы обнаружения на Русской платформе новых среднепалеозойских месторождений алмазов // Региональная геология и металлогения. 2000. № 12. C. $158-177$. https://www.elibrary.ru/item.asp?id $=35627813$ (дата обращения: 12.02.2020).

22. Савко А. Д. Фанерозойские коры выветривания и связанные с ними отложения Воронежской антеклизы, их неметаллические полезные ископаемые: дис. д-ра геол. мин. наук. Воронеж, 1984. 551 c.

23. Аскоченский Б. В., Семенов В. П. Кора выветривания карбонатных пород верхнего мела Воронежской антеклизы. Воронеж: Изд-во Воронеж. ун-та, 1973. 175 с.

24. Савко А. Д., Шевырев Л. Т., Ильяш В. В. Ассоциация минералов-индикаторов алмазоносности в осадочном чехле Воронежской антеклизы. Проблемы алмазной геологии и некоторые пути их решения. Воронеж, 2001. С. 423-433. https://www.elibrary.ru/item.asp?id=29223441 (дата обращения: 12.02.2020).

25. Черешинский А. В., Савко А. Д. Акцессорные минералы базальных горизонтов Воронежской антеклизы (в связи с вопросами алмазоносности). Труды научно-исследовательского института геологии. Воронеж: Изд-во Воронеж. гос. ун-та. Вып. 48, 2007. 120 c. https://www.elibrary.ru/item.asp?id=21768048 (дата обращения: 12.02.2020).

26. Шевырев Л. Т., Черешинский А. В. Алмазоносность центральной части Восточно-Европейской платформы (Boронежская антеклиза). Труды научно-исследовательского института геологии. Воронеж: Изд-во Воронеж. гос. ун-та. Вып. 90, 2015. $283 \quad$ c. https://www.elibrary.ru/item.asp?id=25043240 (дата обращения: 12.02.2020).

27. Савко А. Д., Шевырев Л. Т, . Ильяш В. В., Божко Е. Н. Золото и редкие минералы в осадочном чехле Воронежской антеклизы // Вестник Воронежского государственного университета. Серия: Геология. 1996. №.1. С. 133-138.

28. Наумов В. А., Наумова О. Б. Формы нахождения и перспективы освоения золота в природных и техногенных образованиях Западного Урала // Вестн. Пермск. ун-та. Геология. 2019. Т. 18. № 1. С. 55-63. https://www.elibrary.ru/item.asp?id=38165015 (дата обращения: 12.02.2020). 


\title{
GENERAL AND REGIONAL GEOLOGY
}

UDC 551.7:549:551.2.01(470.32)

ISSN 1609-0691

DOI: https://doi.org/10.17308/geology.2020.1/2509

Received: 14.02.2019

Accepted: 20.02.2020

Published online: 25.03 .2020

\section{Endogenic processes and oregenesis related to them in the phanerozoic of the Voronezh Anteclise}

\author{
(C) 2020 A. V. Chereshinskiy ${ }^{\bowtie}$, L. T. Shevyrev, A. D. Savko
}

Voronezh State University, 1 Universitetskaya pl, Voronezh 394018, Russian Federation

\begin{abstract}
Introduction: The formation and tectonic changes in the structure of the Voronezh anteclise were accompanied by endogenous processes. Their influence was recorded by the presence of volcanic rocks and associated placers of $\mathrm{Ti}, \mathrm{Cu}, \mathrm{Pb}, \mathrm{Zn}$ sulphides, intermetallic compounds, diamonds and their satellite minerals in the sedimentary cover.

Methodology: Maps for various purposes, including geological, facies, and mineralogical were complied. A description of transparent polished sections and thin sections was carried out. The preparations were studied using a binocular microscope and electron microscopy analysis (Jeol 6380LV electron microscope). For the determination of the elemental composition, a local X-ray spectral analysis (OXFORD INS system) and semi-quantitative spectral analysis were used. The mineral composition was studied using an ARL X'TRA powder X-ray diffractometer.

Results and discussion: Endogenous mineralization is usually developed in the zones of Phanerozoic activation, linear areas in which tectonic processes along deep faults are manifested, through which the connection with crustal and mantle sources took place. The continuity of the rocks is impaired in these zones, and they become permeable to magmas, hydrothermal processes, and exhalations. Six epochs of the manifestation of such processes are distinguished: 1 - Early Hercynian $\left(D_{2}-C_{1}\right), 2$ - Late Hercynian $\left(C_{2}-T_{1}\right), 3$ - Early Cimmerian $\left(T_{2}-J_{1}\right), 4$ - Late Cimmerian $\left(J_{2}-K_{1}\right), 5$ - Early Alpine $\left(K_{2}-P_{3}\right), 6$ - Late Alpine (NQ). In $\mathrm{D}_{2}-\mathrm{C}_{1}$ magmatism manifested itself in several stages. The earliest of them is alkalinebasalt in the Kaluga-Belsky structure in the north of the anteclise dates to the Eifelian age. The explosive hawkish in the south-east of the region corresponds to the boundary between the Givetian and the Frasnian. At the beginning of the Late Frasnian (Petinsky) time, to a lesser extent at its end (the EvlanovLivonian), there were outflows of tholeiitic basalts (flow and vent), which formed several fields. Volcanism is associated with mantle sources, as Proterozoic hyperbasites with sulphide copper-nickel mineralization. Exhalative late Hercynian dispersion halo of $\mathrm{Ni}, \mathrm{Co}$, and $\mathrm{Cu}$ in the sedimentary cover were noted above them. Accessory minerals of diamonds appeared in the basal horizons of the Early Carboniferous period. In the Early Cimmerian era, polymetals were formed in the terrigenous-carbonate formations of the coal system in the border areas of the anteclise and the Dnieper-Donets Depression. Basal horizons $\mathrm{J}_{3}$ and $\mathrm{K}_{1}$ contain small diamonds and their accessory minerals, indicating kimberlite (lamproite) magmatism. A new outbreak of magmatism occurred in the early Alpine era, when hydrothermal processes appeared during the formation of granosyenite protrusion of the Shkurlat granite quarry. Fluids received during its upward movement formed ankeritic metasomatite enriched in barite, oligonite, sphalerite, and other minerals along corallite. The Late Alpine era is characterized by exhalation processes with the formation of ultrathin gold and intermetallic compounds enriched in volatile metals in the sedimentary cover.

Conclusions: Endogenous processes superimposed on sedimentary cover rocks have led to the formation of a number of minerals, the prospecting and exploration of which can lead to the discovery of new de-
\end{abstract}

The content is available under Creative Commons Attribution 4.0 License.

Aleksey V. Chereshinskiy, E-mail: vsu31022@mail.ru

Вестник Воронежского государственного университета. Серия: Геология. 2020, № 1, 6-29 
posits for the region. Volcanic-sedimentary placers of titanium with an ilmenite content up to the first hundreds $\mathrm{kg} / \mathrm{m}^{3}$, basalts for ballast rock debris production and stone casting are associated with Devonian magmatism. Basalts and placers of ilmenite in the south-east of anteclise were found in the strip pits of copper-nickel, graphite deposits and over the domes of granitoids, which opens up the possibility for their comprehensive mining. The value of deposits is increased in strip pits of kaolins, quartz sands, chalk, and brick loam. Hydrothermal processes led to the appearance of polymetal ores in the south-west of the anteclise, where a chain of their manifestations was traced in the zones of development of deep faults. In the Cenozoic, the manifestations of ultrathin gold were associated with escalations in the sedimentary cover. One of manifestations is the Russkaya Zhuravka in the south-east, discovered in the last century. However, due to difficulties in metal extraction (7-12\%), exploration was not continued. The conducted diamond potential studies make allowed predicting three epochs of kimberlite magmatism - Late Hercynian, Late Cimmerian, and Early Alpine. The most reliable of them is the second. Therefore, kimberlites should first be explored under the Lower Cretaceous deposits.

Keywords: endogenous processes, volcanic-sedimentary placers of titanium, basalts, $\mathrm{Ni}$ and $\mathrm{Cu}$ scattering halos, polymetals, ultrathin gold, diamonds, minerals-accessory of diamonds.

For citation: Chereshinskiy A. V., Shevyrev L. T., Savko A. D. Endogenic processes and oregenesis related to them in fanerozoic of the Voronezh Anteclise. Vestnik Voronezhskogo gosudarstvennogo universiteta. Seriya: Geologiya = Proceedings of Voronezh State University. Series: Geology, 2020, No. 1, pp. 6-29 DOI: https://doi.org/10.17308/geology.2020.1/2509

Conflict of interests: The authors declare the absence of obvious and potential conflicts of interest related to the publication of this article).

\section{REFERENCES}

1. Shevyrev L. T., Savko A. D., Shishov A. V. Evolyutsiya tektonicheskoy struktury Voronezhskoy anteklizy i ee endogennyy rudogenez. [Evolution of the tectonic structure of the Voronezh anteclise and its ore-forming]. Trudy Nauchnoissledovatel'skogo Instituta Geologii [The work of the Research Institute of Geology], Voronezh, VSU Publ., vol. 25, 2004, 112 p. https://www.elibrary.ru/item.asp?id=21768044 (accessed 12 February 2020). (in Russ.).

2. Shevyrev L. T., Savko A. D. Poleznye iskopaemye zon tektonicheskoy aktivizatsii yuzhnoy chasti Voronezhskoy anteklizy. [Mineral resources of tectonic activization zones of the Southern part of Voronezh anteclise]. Trudy Nauchnoissledovatel'skogo Instituta Geologii [The work of the Research Institute of Geology], Voronezh, VSU Publ., vol. 62, 2011, 106 p. https://www.elibrary.ru/item.asp?id=21768043 (accessed 12 February 2020). (in Russ.).

3. Savko A. D., Khozhainov N. P. Etapy formirovaniya kor vyvetrivaniya $\mathrm{v}$ pozdnem proterozoe i paleozoe Voronezhskoy anteklizy. [Stages of the formation of weathering crusts in the Late Proterozoic and Paleozoic of the Voronezh anteclise]. Litogenez $v$ dokembrii $i$ fanerozoe Voronezhskoy anteklizy. Voronezh, Izd-vo Voronezh. gos. un-ta, 1975, pp. 49-59. https://www.elibrary.ru/item.asp?id=23081099 (accessed 12 February 2020). (in Russ.).

4. Milash A. V., Savko A. D. Litologiya devonskikh otlozheniy yugo-vostoka Voronezhskoy anteklizy. [Lithology of the Devonian deposits of the south-east of the Voronezh antecline]. Trudy Nauchno-issledovatel'skogo Instituta Geologii [The work of the Research Institute of Geology], Voronezh, VSU Publ., vol. 100, 2017, 122 p. https://www.elibrary.ru/item.asp?id=30314171 (accessed 12 February 2020). (in Russ.).

5. Bykov I. N. Verkhnedevonskie bazal'ty na yugo-vostochnoy chasti Voronezhskoy anteklizy. [Upper Devonian basalts in the southeastern part of the Voronezh anteclise]. Voronezh, Izd-vo
Voronezh. gos. un-ta, 1975, 134 p. (in Russ.)

6. Yutkina E. V., Nosova A. A., Sazonova L. V., Larionova Yu. O., Kondrashova I. A., Shumlyanskiy L. V., Al'bekov A. Yu., Savko K. A. Devonian volcanics in the Voronezh Crystalline Massif, East European Platform: Evolution of the melts and characteristics of crustal contamination. Petrology, 2017, vol. 25, no. 3, pp. 241-271. DOI: 10.1134/S0869591117020060

7. Savko A. D., Manukovskiy S. V., Shevyrev L. T. Litologiya i poleznye iskopaemye mamonskoy peschano-kaolinovoy tolshchi Voronezhskoy anteklizy. [Lithology of the Mamonskaya sandy-kaolinic suite of the Voronezh abteclise]. Trudy Nauchnoissledovatel'skogo Instituta Geologii [The work of the Research Institute of Geology], Voronezh, VSU Publ., vol. 53, 2008, 112 p. https://www.elibrary.ru/item.asp?id=21768060 (accessed 12 February 2020). (in Russ.).

8. Ageykin A. S., Chernyshov N. M., Molotkov S. P., Bukovshin V. V. Mednaya i nikelevaya mineralizatsiya $\mathrm{v}$ terrigennykh otlozheniyakh verkhnego devona na yugo-vostoke Voronezhskoy anteklizy. [Copper and nickel mineralization in terrigenous deposits of the Upper Devonian in the southeast of the Voronezh anteclise]. Sov. Geologiya, 1968, no. 1, pp. 122-125. https://www.elibrary.ru/item.asp?id=35548166 (accessed 12 February 2020). (in Russ.).

9. Zelenshchikov G. V., Davydenko D. V. Analiz blokovoy tektoniki yugo-vostochnogo sklona Voronezhskogo kristallicheskogo massiva. [Analysis of block tectonics of the southeastern slope of the Voronezh crystalline massif]. Geotektonika, 1978, no. 3, pp. 38-48. (in Russ.).

10. Chereshinskiy A. V. The indicator minerals of kimberlites of Paleozoic intermediate placer trap of the Voronezh anteclise. Vestnik Voronezhskogo gosudarstvennogo universiteta. Seriya: Geologiya $=$ Proceedings of Voronezh State University. Series: Geology, 2016, no. 1, pp. 76-82. https://www.elibrary.ru/item.asp?id=25942774 (accessed 12 February 2020). (in Russ.).

11. Savko A. D., Shevyrev L. T. Minerageniya osadochnogo chekhla Voronezhskoy anteklizy. [Minerageny of sedimentary cover of the Voronezh anteclise]. Trudy Nauchnoissledovatel'skogo Instituta Geologii [The work of the Research Institute of Geology], Voronezh, VSU Publ., vol. 49, 2007, 99 p. https://www.elibrary.ru/item.asp?id=21763974 (accessed 12 February 2020). (in Russ.).

12. Shumlyanskiy V. A. Kimmeriyskaya metallogenicheskaya epokha na territorii Ukrainy. [Cimmerian metallogenic era in Ukraine]. Kiev: Naukova dumka, 1983, 220 p. (in Russ.).

13. Sushchuk E. G. Starobel'sko-Millerovskiy metallogenicheskiy rayon. [Starobelsko-Millerovsky metallogenic region]. 
Metallogeniya fanerozoya platformennoy chasti Ukrainy. Kiev: Naukova dumka, 1984, pp. 136-139. (in Russ.).

14. Bagno G. F., Mashir V. N. O novykh proyavleniyakh Pb-Zn orudeneniya $\mathrm{v}$ kamennougol'nykh otlozheniyakh na yuzhnom sklone Voronezhskoy anteklizy. [On new manifestations of $\mathrm{Pb}$ $\mathrm{Zn}$ mineralization in coal deposits on the southern slope of the Voronezh anteclise]. Geologicheskiy zhurnal, 1969, no. 1, pp.105-106. (in Russ.).

15. Chereshinskiy A. V. The indicator minerals of kimberlites of the Mesozoic intermediate placer trap of the Voronezh anteclise. Vestnik Voronezhskogo gosudarstvennogo universiteta. Seriya: Geologiya $=$ Proceedings of Voronezh State University. Series: Geology, 2017, no. 2, pp. 107-114. https://www.elibrary.ru/item.asp?id=29407072 (accessed 12 February 2020). (in Russ.).

16. Shilo N. A. Uchenie o rossypyakh. [The doctrine of placers]. Vladivostok: Dal'nauka, 2002, 576 p. http://www.geokniga.org/books/8614 (accessed 12.02.2020). (in Russ.).

17. Vergasova L. P. Naboko S. I., Serafimova V. L., Starova V. L., Filatov S. K. Eksgalyatsionnoe samorodnoe zoloto. [Exhaled native gold]. $D A N, 1982$, vol. 264, no. 1, pp. 201-204. (in Russ.).

18. Chereshinskiy A. V. The indicator minerals of kimberlites of the Cenozoic intermediate placer trap of the Voronezh anteclise Vestnik Voronezhskogo gosudarstvennogo universiteta. Seriya: Geologiya $=$ Proceedings of Voronezh State University. Series: Geology, 2017, no. 3, pp. 75-81. https://www.elibrary.ru/item.asp?id=30005142 (accessed 12 February 2020). (in Russ.).

19. Chereshinskiy A. V. Small diamonds of the Voronezh anteclise: distribution, features, genesis. Vestnik Voronezhskogo gosudarstvennogo universiteta. Seriya: Geologiya = Proceedings of Voronezh State University. Series: Geology, 2015, no. 3, pp. 83-89. https://www.elibrary.ru/item.asp?id=25942718 (accessed 12 February 2020). (in Russ.).

20. Mityukhin S.I. Geologo-geneticheskie i empiricheskie osnovy vydeleniya taksona klassa subprovintsii kimberlitov i konvergentnykh im porod. [Geological-genetic and empirical basis for the allocation of a taxon of the kimberlite subprovination class and rocks convergent to them]. Otechestvennaya geologiya. 1997, no. 1, pp. 23-28. (in Russ.).

21. Mikhaylov M. V., Belyaev G. A., Kuz'mina T. S., Ladygina M. Yu., Polyakov A. A. Perspektivy obnaruzheniya na Russkoy platforme novykh srednepaleozoyskikh mestorozhdeniy almazov. [Prospects for the discovery of new Middle Paleozoic diamond deposits on the Russian platform]. Regional'naya geologiya $i$ metallogeniya, 2000, no. 12 , pp. 158-177. https://www.elibrary. $\mathrm{ru} / \mathrm{item}$. asp?id=35627813 (accessed 12.02.2020). (in Russ.).
22. Savko A. D. Fanerozoyskie kory vyvetrivaniya i svyazannye s nimi otlozheniya Voronezhskoy anteklizy, ikh nemetallicheskie poleznye iskopaemye: dis. d-ra geol. min. nauk. [The phanerozoic weathering crusts and related deposits of the Voronezh anteclise, their non-metallic minerals. Extended Abstract of D.Sc. Thesis]. Voronezh, 1984. 551 p. (in Russ.).

23. Askochenskiy B. V., Semenov V. P. Kora vyvetrivaniya karbonatnykh porod verkhnego mela Voronezhskoy anteklizy. [Weathering crust of carbonate rocks of the Upper Cretaceous of the Voronezh anteclise]. Voronezh, Izd-vo Voronezh. un-ta, 1973, 175 p. (in Russ.).

24. Savko A. D., Shevyrev L. T., Il'yash V. V. Assotsiatsiya mineralov-indikatorov almazonosnosti v osadochnom chekhle Voronezhskoy anteklizy. [Association of the minerals-indicators in the sedimentary cover of the Voronezh anteclise]. Problemy almaznoy geologii i nekotorye puti ikh resheniya. Voronezh, 2001, pp. 423433. https://www.elibrary.ru/item.asp?id=29223441 (accessed 12 February 2020). (in Russ.).

25. Chereshinskiy A. V., Savko A. D. Aktsessornye mineraly bazal'nykh gorizontov Voronezhskoy anteklizy (v svyazi s voprosami almazonosnosti). [The accessory minerals of horizon basal of Voronezh anteclise (in bonding with questions diamondiferousness)]. Trudy Nauchno-issledovatel'skogo Instituta Geologii [The work of the Research Institute of Geology], Voronezh, VSU Publ., vol. 48, 2007, 120 p. https://www.elibrary.ru/ item.asp?id=21768048 (accessed 12 February 2020). (in Russ.).

26. Shevyrev L. T., Chereshinskiy A. V. Almazonosnost' tsentral'noy chasti Vostochno-Evropeyskoy platformy (Voronezhskaya antekliza). [Diamondiferousity of the Central part of the East European platform (Voronezh anteclise)]. Trudy Nauchnoissledovatel'skogo Instituta Geologii [The work of the Research Institute of Geology], Voronezh, VSU Publ., vol. 90, 2015, 283 p. https://www.elibrary.ru/item.asp?id=25043240 (accessed 12 February 2020). (in Russ.).

27. Savko A. D., Shevyrev L. T,. Ilyash V. V., Bozhko E. N. Gold and rare minerals in the sedimentary cover of the Voronezh anteclise. Vestnik Voronezhskogo gosudarstvennogo universiteta. Seriya: Geologiya = Proceedings of Voronezh State University. Series: Geology, 1996, no. 1, pp. 133-138.

28. Naumov V. A., Naumova O. B. Formy nakhozhdeniya i perspektivy osvoeniya zolota $\mathrm{v}$ prirodnykh i tekhnogennykh obrazovaniyakh Zapadnogo Urala. [Forms of Location and Prospects of Gold Mining Potential in Natural and Technogenic Mineral Formations of the Western Urals]. Proceedings of Perm State University. Series: Geology, 2019, Vol. 18, no. 1, pp. 5563. https://www.elibrary.ru/item.asp?id=38165015 (accessed 12.02.2020). (in Russ.).

\begin{abstract}
Черешинский Алексей Васильевич - к. г.-м. н., доцент, Воронежский государственный университет, Воронеж, Российская Федерация; E-mail: vsu31022@ mail.ru;

ORCID https://orcid.org/0000-0003-0697-3551

Шевырев Леонид Тихонович - д. г.-м. н., Воронежский государственный университет, Воронеж, Российская Федерация; E-mail: shevpp@yandex.ru;

ORCID https://orcid.org/0000-0002-3468-6712

Савко Аркадий Дмитриевич - Д. г.--м. н., профессор, Воронежский государственный университет, Воронеж, Российская Федерация; E-mail: savko@ geol.vsu.ru;

ORCID https://orcid.org/0000-0003-2133-3317
\end{abstract}

Авторы прочитали и одобрили окончательный вариант рукописи.
Alexey V. Chereshinskiy - PhD in Geol-Min., Associate Professor, Voronezh State University, Voronezh, Russian Federation; E-mail: vsu31022@mail.ru; ORCID https://orcid.org/0000-0003-0697-3551

Leonid T. Shevyrev - PhD, Dr. habil. in Geol.-Min, Voronezh State University, Voronezh, Russian Federation;

E-mail: shevpp@yandex.ru;

ORCID https://orcid.org/0000-0002-3468-6712

Arkadiy D. Savko - PhD, Dr. habil. in Geol.-Min, Professor,

Voronezh State University, Voronezh, Russian Federation; Email: savko@geol.vsu.ru; ORCID https://orcid.org/0000-0003-2133-3317

All authors have read and approved the final manuscript. 